\title{
Pendulous Usnea species (Pameliaceae, lichenized Ascomycota) in tropical South America and the Galapagos
}

\author{
Camille TRUONG, Juan Manuel RODRIGUEZ and Philippe CLERC
}

\begin{abstract}
The diversity of pendulous Usnea species in tropical South America (Bolivia, Brazil, Colombia, Ecuador, Paraguay, Peru and Venezuela) and the Galapagos Islands is discussed with reference to 23 species. Usnea crenulata Truong \& Clerc is newly described. Usnea articulata, U. deformis, $U$. dimorpha, U. geissleriana, U. merrillii, U. perhispidella, U. sanctaeritae, U. subflammea and U. transitoria are newly reported for South America. Modern descriptions are provided for Usnea amabilis, $U$. arthroclada, $U$. dodgei, $U$. humboldtii and $U$. regia. We propose to reject the synonymy of $U$. hesperina with $U$. schadenbergiana, and the valid name for $U$. hesperina is therefore $U$. subgracilis. Distinct patterns of unidentified triterpenoids have been detected by thin-layer chromatography and are used to characterize several species within this group. The morphology, branch anatomy, chemistry, ecology and distribution of each species are given, together with an identification key.
\end{abstract}

Key words: endemism, lichens, macrolichens, Neotropics, taxonomy

Accepted for publication 19 fanuary 2013

\section{Introduction}

Usnea is one of the largest genera within the family Parmeliaceae (Lecanorales, Ascomycota), and is estimated to comprise more than 350 species (Clerc 1998), widely distributed in polar, temperate and tropical regions. The genus is well-characterized by a fruticose thallus, branches with a cartilaginous central axis and the presence of usnic acid in the cortex. The delimitation of species is considerably challenged by the extensive plasticity of morphological characters in response to environmental parameters (Clerc 1998) and numerous taxa have recently been reduced to synonymy. Since Motyka's world monograph $(1936,1938)$, taxonomic revisions have been carried out in Europe (Clerc 1987b,

C. Truong and P. Clerc: Conservatoire et Jardin Botaniques de la Ville de Genève, CP 60, 1292 Chambésy, Switzerland ; Laboratoire de Systématique Végétale et Biodiversité, Faculté des Sciences de l'Université de Genève, CP 60, 1292 Chambésy, Switzerland. Email: camille.truong@ville-ge.ch

J. M. Rodriguez: Centro de Ecología y Recursos Naturales Renovables, Facultad de Ciencias Exactas, Físicas y Naturales, Universidad Nacional de Córdoba, CONICET, Av. Vélez Sarsfield 299, Córdoba, Argentina.
1992, 2011b; Halonen et al. 1999), Macaronesia (Clerc 2006), North America (Clerc \& Herrera-Campos 1997; Halonen et al. 1998; Herrera-Campos et al. 1998, 2001; Clerc 2008), East Africa (Swinscow \& Krog 1978, 1979), Eastern Asia (Ohmura 2001, 2012; Ohmura et al. 2010), Australia (Stevens 1999, 2004), India (Awasthi 1986) and the polar regions (Walker 1985; Seymour et al. 2007; Wirtz et al. 2008; Lumbsch \& Wirtz 2011).

In the Neotropics, Usnea species are found abundantly in montane forests, especially close to the tree limit (Arvidsson 1991; Sipman 1995, 1999) or in open meso-habitats in the vicinity of the forest, such as isolated oldgrowth trees within pastures, forest borders (along roads) or deforested zones of matorral (Truong et al. 2011). In the Galapagos, Usnea species are encountered in all vegetation belts except in the coastal zone, with the highest diversity and abundance in the transition zone (see Aptroot \& Bungartz 2007 for details on vegetation zones), probably related to the occurrence of fog (Truong et al. 2011). Numerous Usnea species, as currently understood, have a cosmopolitan distribution and the Usnea flora of South America 
integrates elements from North America, tropical Africa, Macaronesia and even Asia (Truong et al. 2011). An ongoing taxonomic investigation of the diversity of Usnea species was recently started in South America and the Galapagos (Rodriguez et al. 2011; Truong et al. 2011; Truong \& Clerc 2012). It contributes to further elucidate the level of endemism in the Galapagos, as well as providing a better understanding of this genus worldwide. This study is a further step, treating the pendulous species from tropical South America and the Galapagos.

\section{Materials and Methods}

This study is based mainly on material collected by the authors in Bolivia, Ecuador (including the Galapagos) and Peru, as well as herbarium specimens collected in Brazil and Paraguay by K. Kalb (private hb.) and A. Spielmann (SP), in Colombia by H. Sipman (B) and in Venezuela by M. E. Hale, Jr. (US). See Truong et al. (2011) for a detailed description of the collection sites. Specimens and types from the following herbaria were included: BM, G, H, LBL, MEXU, OXF, S, TUR, UPS, W and WU. Only names that have been cited in South America are mentioned in the list of synonyms in the species descriptions.

Morphology of specimens was examined using a Leica MS5 stereomicroscope. See previous publications (e.g. Clerc 1987a, 1998, 2011b; Clerc \& Herrera-Campos 1997; Herrera-Campos et al. 1998; Ohmura 2001; Truong et al. 2011) for detailed descriptions of the characters used in the delimitation of Usnea species. Shape of branch and branch segments are especially valuable to describe pendulous Usnea species and an illustration of these characters is provided in Clerc (2011b). In the species descriptions, the size of soralia and tubercles will be referred to as minute (less than the half-branch diameter) or large (more than the half-branch diameter).

Anatomical measurements of cortex, medulla and central axis were realized in longitudinal section of branch at $\times 40$ magnification. The percentage thickness of cortex/medulla/axis of the total branch diameter (CMA) and the ratio of axis/medulla (A/M) were calculated according to Clerc (1987b). In the description of species, CMA values are given with their standard deviations and follow the categories described by Clerc (2011b).

Chemical analyses were performed by thin-layer chromatography (TLC) following the method of Culberson \& Ammann (1979), with solvent B modified according to Culberson \& Johnson (1982).

\section{Results}

A total of 905 specimens were studied. The number of specimens studied for each spe- cies, as well as their distribution per country and altitudinal ranges, is found in Table 1. Usnea crenulata is newly described and nine species are newly reported for South America. Usnea alata, $U$. crenulata and $U$. regia are so far endemic to South America, whereas $U$. amabilis, $U$. arthroclada, $U$. deformis, $U$. dodgei, U. firma, U. humboldtii, U. malmei, $U$. mexicana, U. papillata, $U$. sancteritae and $U$. transitoria are so far endemic to the Neotropics (occurring in Central America as well). Usnea mexicana and U. dodgei occur in the Galapagos, but also on the South American mainland.

For each species, CMA values and A/M ratios are illustrated in Fig. 1. They have proved to be very good diagnostic characters in the delimitation of Usnea species (Clerc 1998; Truong et al. 2011).

The species exhibit one to four chemotypes that are described in Table 2. Triterpenoids have been previously reported from North American (Halonen et al. 1998) and eastern Asian (Ohmura 2001) species, and seem to be particularly abundant in Neotropical species (Truong et al. 2011). Their detection is realized under the UV lamp after charring (before that step, they are often undetectable or may be mistaken for fatty acids). Although the exact nature of these triterpenoids remains unknown, they occur in distinctive patterns, as illustrated in Fig. 2. These patterns are often characteristic of each species and can be used for their identification.

\section{Thallus erect versus pendulous}

By definition, a pendulous thallus exhibits branches running parallel almost from the base to the apices, and hanging downwards (see illustrations in Herrera-Campos et al. 1998; Ohmura 2001). Usnea angulata, $U$. malmei and $U$. subgracilis are typically pendulous. In subpendulous thalli, branches are first diverging and erect, then rapidly run parallel and hang down, at least before reaching half of the thallus length. Usnea dodgei (Fig. 7D), U. geissleriana and U. subscabrosa are typically subpendulous. In erect thalli, branches remain erect and divergent to the apices. Although pendulous thalli are usually 
TABle 1. Distribution per country and altitudinal ranges of the pendulous Usnea species in tropical South America and the Galapagos Islands.

\begin{tabular}{|c|c|c|c|c|c|c|c|c|c|c|c|}
\hline Species & $n$ & BOL & BRA & COL & ECU & GAL & PAR & PER & VEN & Altitude (SAM) & $\begin{array}{c}\text { Altitude } \\
\text { (GAL) }\end{array}$ \\
\hline U. alata & 17 & + & + & & & & + & & & $150-1400$ & \\
\hline U. amabilis & 43 & + & & + & + & & & + & + & (900) 1700-2950 & \\
\hline U. angulata & 184 & + & + & + & & ext & + & + & + & (0) 500-3050 & \\
\hline U. arthroclada & 23 & & + & & & & & & & $1600-1850$ & \\
\hline U. articulata* & 3 & & + & & & & & & & $?$ & \\
\hline U. crenulata*** & 26 & + & & + & & & & + & + & $2100-3100$ & \\
\hline U. deformis* & 12 & + & & + & & & & + & + & $2200-4200$ & \\
\hline U. dimorpha* & 26 & & + & + & + & & & + & + & (500) 2000-3500 & \\
\hline U. dodgei & 50 & & + & + & & + & & + & + & (450) $1000-3000$ & $150-1100$ \\
\hline U. firma & 33 & & + & & & & & & & $1500-2000$ & \\
\hline U. geissleriana* & 16 & + & + & & + & & & + & + & (900) 2400-3200 & \\
\hline U. humboldtii & 3 & & + & & & & & & + & $?$ & \\
\hline U. malmei & 82 & & + & + & & & & + & + & (650) 1250-2950 & \\
\hline U. merrillii* & 8 & & + & & & & & & + & $800-2600$ & \\
\hline U. mexicana & 51 & + & + & + & + & + & & + & + & $500-3050$ & $250-1050$ \\
\hline U. papillata & 9 & + & + & & & & & & & $1000-2000$ & \\
\hline U. perhispidella* & 18 & + & + & + & + & & & + & & (100) 1000-3050 & \\
\hline U. regia & 44 & + & + & & + & & & & + & (850) 1400-3000 & \\
\hline U. sanctaeritae* & 4 & & + & & & & & & & $1600-2000$ & \\
\hline U. subflammea* & 59 & + & + & + & + & & & + & + & $(700) 1600-3200$ & \\
\hline U. subgracilis & 118 & + & + & + & + & & & + & + & $1700-3500$ & \\
\hline U. subscabrosa & 74 & + & + & + & + & & & + & + & $(700) 1700-3400$ & \\
\hline U. transitoria* & 2 & & & & & & & & + & $1600-2000$ & \\
\hline
\end{tabular}

BOL, Bolivia; BRA, Brazil; COL, Colombia; ECU, Ecuador (continental); GAL, Galapagos; PAR, Paraguay; PER, Peru; VEN, Venezuela; SAM, continental South America; $n$, number of specimens studied; + , presence; ext, extinct; ***newly described species; *newly reported for South America; altitudes in metres.

long (10 $\mathrm{cm}$ or more) while erect thalli are short (a few $\mathrm{cm}$ ), the size is not a criterion for the definition of a pendulous versus erect thallus: in the Neotropics, several erect species (e.g. U. columbiana) may exhibit thalli of large size, but retain diverging branches. The definition of an erect, subpendulous or pendulous thallus can be considered as an intrinsic character of most Usnea species that is subsequently modulated by environmental conditions. Several species that are primarily erect can occasionally exhibit a subpendulous thallus when environmental conditions are optimal, especially a high level of humidity. For example, subpendulous thalli of typ- ically erect species are common in the Neotropics (U. columbiana Motyka, U. rubicunda Stirt., U. cornuta Körb.), but these specimens are however never truly pendulous, or only on exceptional occasions (pendulous forms of $U$. columbiana were observed on a saxicolous substratum in Argentina). Similarly, young or poorly developed specimens of subpendulous (rarely pendulous) species can occasionally appear erect.

Usnea species usually hold from a single or few well-visible trunks. One particular case is illustrated by species holding on to the substratum from several inconspicuous attachment points, or hapters. As a consequence, 

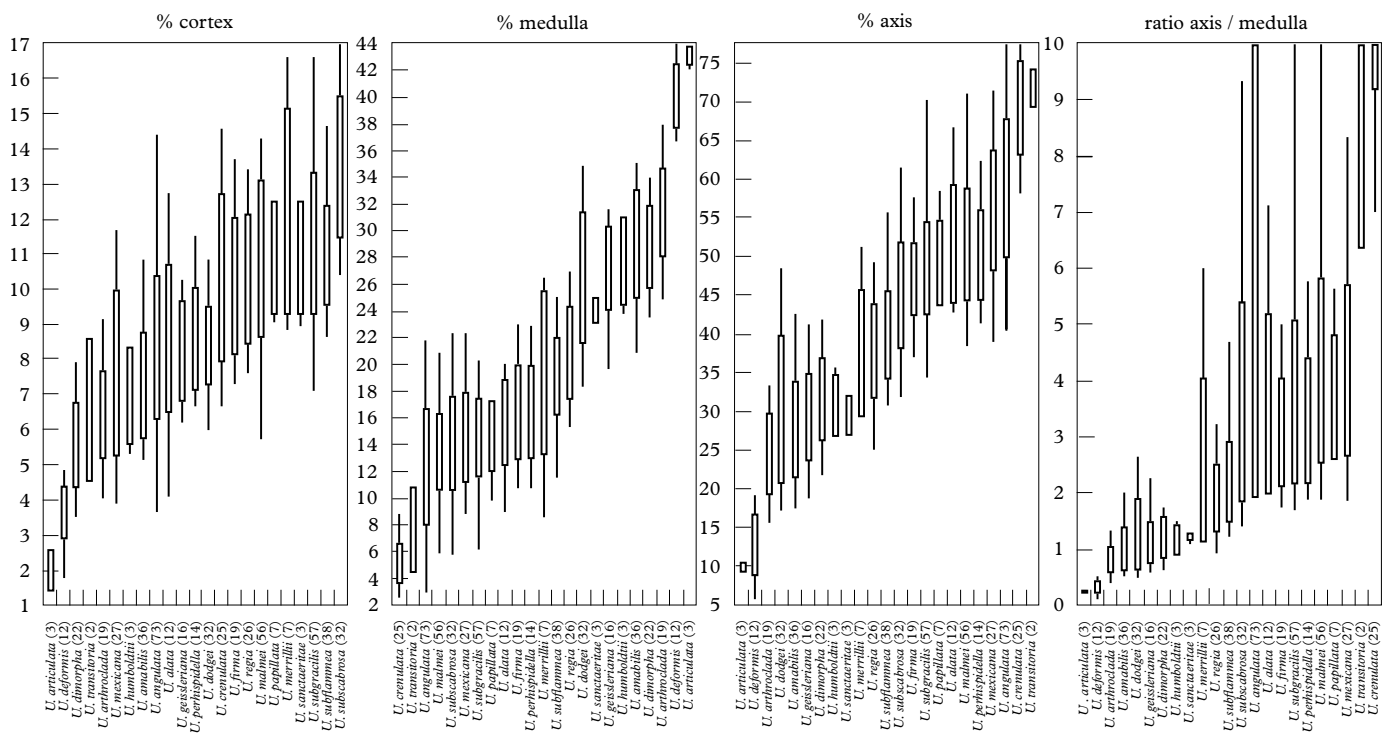

FIg. 1. Percentage of cortex/medulla/axis (CMA) and axis/medulla ratio (A/M) of total branch diameter. Standard deviations as wide bars; extreme values as lines; numbers of specimens measured in parentheses.

their branches tend to wrap around the substratum (tree branches) and become entangled. Usnea amabilis (Fig. 3A), U. crenulata and $U$. merrilii typically have what we will call 'entangled' thalli. Species with entangled thalli often have long thalli with thin branches that may end up running parallel towards the apices, but they are usually more subpendulous than truly pendulous. The ability to produce hapters can be considered an intrinsic character in Usnea and is therefore of taxonomic importance in the delimitation of species.

In this study we describe the species which are primarily pendulous, subpendulous or entangled. Erect species that are occasionally subpendulous are only included in the identification key.

\section{The Species}

\section{Usnea alata Motyka}

Lich. Gen. Usnea Stud. Monogr. Pars Sys. 2: 395 (1938); type: Brazil, Minas Geraes, 1885, Chequeira (TURV00493!-lectotype; S! - isolectotype). \% C/M/A: 9/15/ 52. Chemistry: usnic, norstictic and connorstictic acids (Herrera-Campos et al. 1998).
Usnea sulcata var. sulcata Motyka syn. nov., Lich. Gen. Usnea Stud. Monogr. Pars Sys. 2: 478 (1938); type: Brazil, Minas Geraes, Sitio, 1885, Vainio (LBL-lectotype). Chemistry: usnic, caperatic, norstictic and connorstictic acids (Ohmura 2001).

Usnea neutra (Motyka) Rizzini, syn. nov., Revista Brasil. Biol. 12: 340 (1952).- -Usnea sulcata var. neutra Motyka, Lich. Gen. Usnea Stud. Monogr. Pars Sys. 2: 480 (1938); type: Brazil, Cidade de Caldas, 1879, Regnell (S!-lectotype). \% CMA: 5·5/11 5/67. Chemistry: usnic, norstictic and connorstictic acids (Lendemer, indicated on a label in $S$ ).

Nomenclatural notes. We were not able to trace the lectotype specimen of $U$. sulcata var. sulcata in LBL, so we have based our synonymy on the descriptions of Motyka (1938) and Lendemer \& Tavares (2004). Lendemer \& Tavares (2004) stated that the lectotype specimen of $U$. sulcata var. neutra contains stictic in addition to norstictic acid, but the label left on the specimen sheet indicates that it contains only norstictic acid.

Diagnostic notes. See under $U$. angulata for a detailed description, this species differing from $U$. angulata only in the absence of soralia. This is a pendulous, non-sorediate species, usually with alate branches usually holding lateral apothecia.

Variation. Usnea alata presents similar morphological variation to $U$. angulata in the shape of branch segments (strongly alate to 
TABLE 2. Major secondary metabolites (columns) and chemotypes (lines) detected by TLC in the medulla of pendulous Usnea species.

\begin{tabular}{|c|c|c|c|c|c|c|c|c|c|c|c|c|c|}
\hline \multicolumn{2}{|c|}{ Species/chemotype } & \multirow{2}{*}{$\frac{n}{7}$} & \multirow[t]{2}{*}{ PRO } & \multirow[t]{2}{*}{ SAL } & \multirow[t]{2}{*}{ GAL } & \multirow{2}{*}{$\frac{\text { NOR }}{+}$} & \multirow{2}{*}{\begin{tabular}{|c|}
$\mathrm{CNO}$ \\
\pm
\end{tabular}} & \multirow[t]{2}{*}{ STI } & \multirow[t]{2}{*}{ CsT } & \multirow[t]{2}{*}{ DIF } & \multirow{2}{*}{$\frac{\text { TER }^{*}}{ \pm}$} & \multirow{2}{*}{$\begin{array}{c}\text { K reaction } \\
\text { yellow turning orange-red }\end{array}$} & \multirow{2}{*}{$\begin{array}{c}\text { P reaction } \\
\text { deep yellow }\end{array}$} \\
\hline U. alata & $/ 1$ & & & & & & & & & & & & \\
\hline & $/ 2$ & 5 & & & & & & & & & + & - & - \\
\hline & $/ 3$ & 3 & & & & & & & & & + & - & - \\
\hline U. amabilis & & 41 & & & & & & & + & \pm & & yellow turning red & yellow-orange \\
\hline \multirow[t]{4}{*}{ U. angulata } & $/ 1$ & 125 & & & & + & \pm & & & & \pm & yellow turning orange-red & deep yellow \\
\hline & $/ 2$ & 9 & & & & $\mathrm{t}$ & & + & + & & \pm & yellow slowly turning orange & deep orange \\
\hline & $/ 3$ & 3 & & & & & & & & & + & - & - \\
\hline & $/ 4$ & 3 & & & & & & & & & + & - & - \\
\hline U. arthroclada & & 15 & & & & $\mathrm{t}$ & & + & + & & & yellow slowly turning orange & deep orange \\
\hline U. articulata & & 3 & $\pm \mathrm{t}$ & + & & + & & & & & & yellow turning red & yellow-orange \\
\hline \multirow[t]{3}{*}{ U. deformis } & $/ 1$ & 6 & & & & & & + & + & & + & yellow slowly turning orange & deep orange \\
\hline & $/ 2$ & 5 & & & & $\mathrm{t}$ & & + & + & & & yellow slowly turning orange & deep orange \\
\hline & $/ 3$ & 2 & & + & + & + & & & & & & yellow turning red & yellow-orange \\
\hline U. dimorpha & & 24 & & \pm & + & + & & & & & \pm & yellow turning red & yellow-orange \\
\hline \multirow[t]{3}{*}{ U. dodgei } & $/ 1$ & 27 & & & & + & + & & & & + & yellow turning orange-red & deep yellow \\
\hline & $/ 2$ & 22 & & & & $\mathrm{t}$ & & + & + & & + & yellow slowly turning orange & deep orange \\
\hline & $/ 3$ & 3 & & + & \pm & + & & & & & + & yellow turning red & yellow-orange \\
\hline U. crenulata & & 23 & & & & & & & & & + & - & - \\
\hline U. firma & & 19 & + & & & & & & & & & - & yellow-orange \\
\hline \multirow[t]{2}{*}{ U. geissleriana } & $/ 1$ & 11 & & & & $\mathrm{t}$ & & + & + & & & yellow slowly turning orange & deep orange \\
\hline & $/ 2$ & 6 & & + & & \pm & & & & & & yellow turning red & yellow-orange \\
\hline U. humboldtii & & 3 & & & & & & & + & \pm & & yellow turning red & yellow-orange \\
\hline \multirow[t]{3}{*}{ U. malmei } & $/ 1$ & 33 & & & & $\mathrm{t}$ & & + & + & & + & yellow slowly turning orange & deep orange \\
\hline & $/ 2$ & 16 & + & & & & & & & & + & - & yellow-orange \\
\hline & $/ 3$ & 4 & & & & & & & & & + & - & - \\
\hline \multirow[t]{2}{*}{ U. merrillii } & $/ 1$ & 6 & & + & & & & & \pm & & & yellow turning red & yellow-orange \\
\hline & $/ 2$ & 1 & & + & + & + & & & & & & yellow turning red & yellow-orange \\
\hline \multirow[t]{3}{*}{ U. mexicana } & $/ 1$ & 13 & $\pm \mathrm{t}$ & $\pm \mathrm{t}$ & & & & & \pm & + & & yellow turning red or yellow & yellow-orange or - \\
\hline & $/ 2$ & 12 & + & & & & & & & & & - & yellow-orange \\
\hline & $/ 3$ & 1 & & & & & & & + & & & yellow turning red & yellow-orange \\
\hline \multirow[t]{3}{*}{ U. papillata } & $/ 1$ & 3 & & & & $\mathrm{t}$ & & + & + & & + & yellow slowly turning orange & deep orange \\
\hline & $/ 2$ & 3 & & & & & & & & & + & - & - \\
\hline & $/ 3$ & 1 & & & & + & & & & & + & yellow turning orange-red & deep yellow \\
\hline U. perhispidella & & 13 & & & & $\mathrm{t}$ & & + & + & & & yellow slowly turning orange & deep orange \\
\hline U. regia & & 30 & & & & $\mathrm{t}$ & & + & + & & & yellow slowly turning orange & deep orange \\
\hline U. sanctaeritae & & 3 & & + & + & + & & & & & & yellow turning red & yellow-orange \\
\hline U. subgracilis & & 86 & + & & & & & & & & & - & - \\
\hline U. subflammea & $/ 1$ & 23 & & \pm & + & + & & & & & & yellow turning red & yellow-orange \\
\hline & $/ 2$ & 18 & & & & $\mathrm{t}$ & & + & + & & & yellow slowly turning orange & deep orange \\
\hline U. subscabrosa & & 32 & + & & & & & & & & & - & yellow-orange \\
\hline U. transitoria & & 2 & & & & $\mathrm{t}$ & & + & + & & & yellow slowly turning orange & deep orange \\
\hline
\end{tabular}

PRO, protocetraric; SAL, salazinic; GAL, galbinic; NOR, norstictic; CNO, connorstictic; STI, stictic; CST, constictic; DIF, diffractaic acid; TER, unidentified triterpenoids (*see TLC patterns in Fig. 2); n, number of specimens studied; + , presence constant within species; \pm , presence variable among specimens within species; $t$, present in traces. 


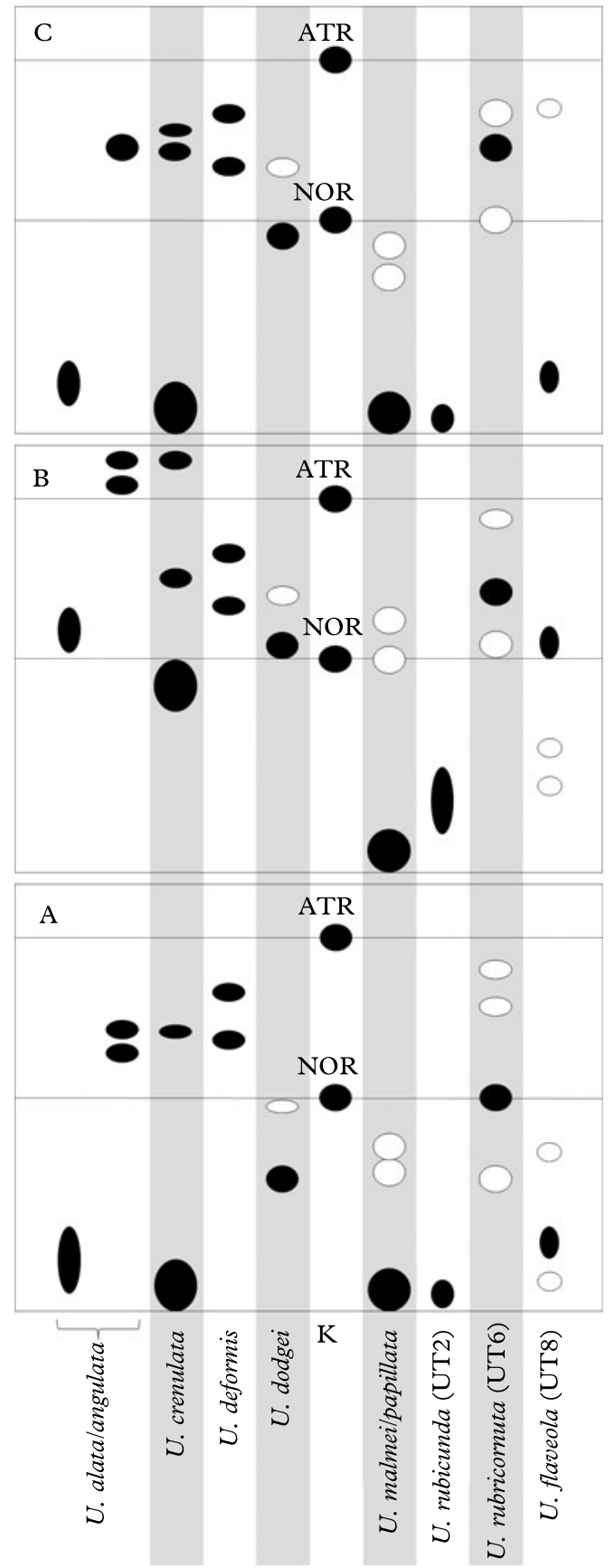

Fig. 2. Patterns of unidentified triterpenoids detected by TLC in the medulla using the solvents A, B and C . $\bullet$, presence constant within species; $O$, presence variable between individuals within species. These patterns are diagnostic to identify the species listed here. squamulose, sometimes only ridged to crenulate towards the apices). When apothecia are absent, pycnidia may occur as globose protuberances on lateral branches or fibrils.

In addition to norstictic acid, two chemotypes with distinct patterns of unidentified triterpenoids were detected (Fig. 2). All these chemotypes exhibited a similar morphology. The very large variation in the axis thickness and $\mathrm{A} / \mathrm{M}$ ratio might possibly hide more than one taxon: a few specimens with triterpenoids and an $\mathrm{A} / \mathrm{M}$ ratio $>10$ were kept under $U$. alata s. lat. until more material is available to be studied.

Although the lectotype specimen of $U$. alata chosen by Lendemer \& Tavares (2004) contains norstictic acid in the medulla, Motyka's diagnosis indicates that the medulla of $U$. alata reacts $\mathrm{K}-$, which is consistent with the presence of triterpenoids. Lendemer \& Tavares (2004) identified the presence of caperatic acid in the lectotype of Usnea sulcata var. sulcata, as well as in several herbarium specimens, but so far we have not detected caperatic acid in our TLC analyses.

Ecology. Riparian or semi-deciduous forests, forest border, exposed sites in cerrado, at relatively low altitudes (often below $1000 \mathrm{~m}$ ); corticolous.

Distribution. Bolivia, Brazil, Paraguay; so far endemic to continental South America (Motyka 1936).

Selected specimens examined. Bolivia: La Paz: $15 \mathrm{~km}$ de Camata hacia Apolo, $1400 \mathrm{~m}, 1997$, Bach et al. 222 (B).-Brazil: Minas Gerais: Parque estatual de Ibitipoca, by administration, $1250 \mathrm{~m}, 1993$, Marcelli et al. 28035 (H). Paraná: P.N. do Iguaçu, near Iguaçu falls, 200 m, 1952, Mattick 1002 (B). Rio Grande do Sul: Vacaria, Fazenda da Estrela, margem do rio Frade, $860 \mathrm{~m}$, 2007, Spielmann 4806 (SP). São Paulo: Fazenda 13 de maio, $18 \mathrm{~km}$ nördlich von Botukatu und $14 \mathrm{~km}$ östlich von São Manuel, 550 m, 1979, Kalb E Plöst (private hb.).-Paraguay: Gran Chaco: Zwischen B. Aceval und Algarrobo, $150 \mathrm{~m}, 1980$, Kalb (private hb.). Itapúa: Cantera, sobre el rió Paraná, 1957, Montes 12039 (H). Paraguari: Sierro Negro, 1893, Malme (H).

\section{Usnea amabilis Motyka}

Lich. Gen. Usnea Stud. Monogr. Pars Sys. 2: 628 (1938); type: Bolivia, La Paz, 1891, Bang (H-NYL 36380!holotype). \% C/M/A: 7/31/24. Chemistry: usnic and constictic acids. 


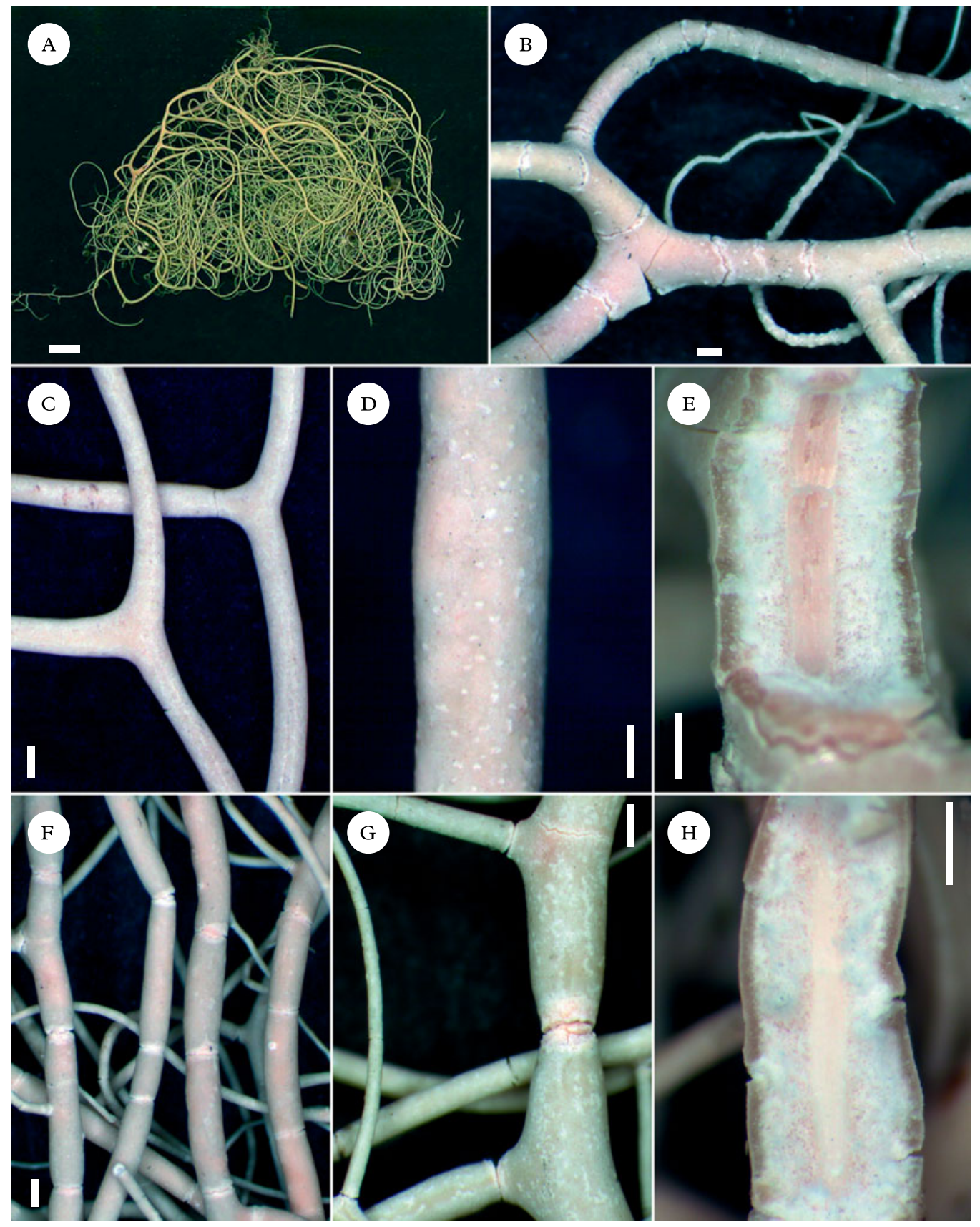

FIG. 3. A-E, Usnea amabilis; A, thallus entangled with several inconspicuous attachment points and branches wrapping around the substratum (Truong 3871); B, annulations of branches eroded at edges (Truong 3871); C, branch segments flattened and enlarged at ramifications (Truong 3868); D, minute pseudocyphellae on main branches (Truong 2509); E, section of branch (Bach et al. 8). F-H, Usnea arthroclada (Kalb E Plöbst); F, branches segmented into slightly inflated segments; $G$, whitish maculae spotting the cortex surface of branches, annulations eroded at edges (whitish), with a \pm dented margin; $\mathrm{H}$, section of branch. Scales: $\mathrm{A}=1 \mathrm{~cm} ; \mathrm{B}-\mathrm{H}=500 \mu \mathrm{m}$. In colour online. 


\section{(Fig. 3A-E)}

Thallus entangled, with several inconspicuous hapters and branches wrapping around the substratum (Fig. 3A), to more than 50 $\mathrm{cm}$ long; ramifications mostly anisotomicdichotomous, with large and visible main branches contrasting with thin lateral/terminal branches (undeveloped thalli with only thin branches); trunk with several hapters, often inconspicuous, concolorous with the branches; branches irregular, regularly segmented with annulations that are often eroded at edges with a \pm dentate margin on basal branches (Fig. 3B), annulations remaining thin on terminal branches; branch segments slightly to strongly flattened, not to slightly swollen (main branches); lateral branches slightly to distinctly enlarged and flattened at ramification (visible mostly on secondary branches, Fig. 3C); maculae absent or faint, together with an irregularly pruinose cortex surface; foveoles absent or rare on main branches; pseudocyphellae minute, inconspicuous (young thalli) to very distinctive on main branches (Fig. 3D); papillae and tubercles absent; fibrils absent or few and irregularly dispersed on terminal branches (young branches?); fibercles absent; soralia scarce, often lacking, minute and plane, developing on lateral/terminal branches from the cortex ad initio, on mature thalli also developing from pseudocyphellae on main branches; isidiomorphs short, few to numerous; cortex moderately thin to moderately thick (5.5$9.0 \%)$, matt in section, cortex surface slightly to strongly pruinose; medulla moderately thin to thick $(21 \cdot 5-33 \cdot 0 \%)$, dense, looser towards the axis (Fig. 3E); axis thin to moderately thin $(21-34 \%)$, often faintly pigmented in pink to orange, with an $\mathrm{A} / \mathrm{M}$ ratio $<1.5$ (Fig. 1).

Apothecia rare $(n=3)$, lateral.

Pycnidia not seen.

Diagnostic notes. Usnea amabilis is characterized by an entangled thallus, with branches wrapping around the substratum and several inconspicuous attachment points. Ramifications are mostly anisotomic-dichotomous, with large and irregular main branches contrasting with thin, almost filamentous termi- nal branches. The cortex surface of branches is \pm pruinose, with minute pseudocyphellae most conspicuous on main branches. The cortex is matt in section and the medulla dense, reacting $\mathrm{K}+$ yellow turning red (constictic acid, Table 2).

Variation. Young thalli may present only very thin branches, with inconspicuous pseudocyphellae, similar to terminal branches of well-developed thalli. This species is either sorediate (soralia often scarce), or nonsorediate (apothecia seldom and often without apothecia or soralia). Following the speciespair concept of Poelt (1970) that is traditionally used in Usnea, sorediate and nonsorediate specimens should be considered as distinct taxa. We prefer to consider all of them under $U$. amabilis until a deeper taxonomic treatment is made with molecular studies.

Differentiation. See under $U$. arthroclada and $U$. geissleriana. Usnea regia shares the irregular, anisotomic-dichotomous branches and the matt and pruinose cortex. It differs in the pendulous thallus (not entangled), usually with a single, well-visible and annulated trunk (rarely a few secondary hapters may be present), and conspicuous maculae drawing a network on the cortex surface of main branches, instead of minute pseudocyphellae in U. amabilis. Usnea amabilis is occasionally faintly maculate, but maculae are never as conspicuous and occur together with pseudocyphellae. Soralia in $U$. regia are distinctly stipitate and may enlarge at maturity. It has a thicker cortex and a thinner, compact medulla, with a pinkish periaxial pigmentation (within the axis in $U$. amabilis) and an $\mathrm{A} / \mathrm{M}$ ratio $>1 \cdot 25$ (Fig. 1). Both species also have different chemotypes (Table 2).

Ecology. Primary and secondary forests (mountain cloud forests, evergreen low montane forests, Quercus woods) or open sites such as isolated trees in pastures, always in the vicinity of the forest; primarily corticolous, occasionally lignicolous (fence posts).

Distribution. Tropical Andes; also reported from Central America (Motyka 1936). 
Selected specimens examined. Bolivia: Beni: $20 \mathrm{~km}$ por carretera maderera al SW del km 12 Yucumo - Rurrenabaque., 900 m, 1997, Bach 392 (B). La Paz: P.N. Cotapata, ruta de la muerte, $2348 \mathrm{~m}, 2007$, Truong 3869 (G). Cochabamba: $10 \mathrm{~km}$ de Cocapata hacia Cotacajes, 2800 m, 1997, Bach 8 (B).-Colombia: Cauca: Timbío, Hatoviejo, 1900 m, 1939, Cuatrecasas 6098 (US). Cundinamarca: Alto de Sendales, 2750 m, 1972, Cleef 6050 (B). Huila: headwaters of Rio La Candelaria, 2300 m, 1984, Aguirre E Sipman 6175 (B). Nariño: along main road to Popayan, 2550 m, 1986, Sipman 33640 (B). Santander: between La Paz and Recreo, 1370 m, 1944, Fassett 25197 (US).-Ecuador: Loja: Ruta nueva hasta Saragura cerca de Cenen, $2708 \mathrm{~m}, 2007$, Truong 3873 (G).-Panama: Chiriqui: $3 \mathrm{~km}$ south of Volcan, 1700 m, 1973, Hale 38830 (US).-Peru: Cusco: centro de investigación Wayqecha, trocha Oso, $2534 \mathrm{~m}, 2007$, Truong 2267 (G). Huanuco: Bosque de Carpish, 2246 $\mathrm{m}, 2007$, Truong 2718 (G). Pasco: P.N. YanachagaChemillén, trocha hasta la ambra Esperanza, $2554 \mathrm{~m}$, 2007, Truong 2509 (G).-Venezuela: Anzoategui: headwaters of Quebrada la Tigra, $1800 \mathrm{~m}$, Steyermark 61546 (US). Merida: La Carbonera, via Merida-La Azulita, 2200 m, 1975, Hale $\&$ Lopez-Figueiras 44255 (US).

\section{Usnea angulata Ach.}

Synops. Lich.: 307 (1814); type: America septentrionalis, Muhlenberg 22-2 (H!-lectotype, designated by Motyka 1938: 394). \% C/M/A: 8/4·5/74. Chemistry: usnic and norstictic acids (Herrera-Campos et al. 1998).

Usnea paradoxa Motyka syn. nov., Lich. Gen. Usnea Stud. Monogr. Pars Sys. 2: 482 (1938), cited by Motyka as $U$. paradoxa (Zahlbr.) Motyka (Lendemer \& Tavares 2003); type: Brazil, Pico de Tijucca, 1879, Wawra (W!-lectotype; S!-isotype). \% C/M/A: 10·5/16/47. Chemistry: usnic, norstictic and connorstictic acids.

\section{(Fig. 4A-E)}

Diagnostic notes. Detailed descriptions are available in Herrera-Campos et al. (1998) and Ohmura (2001). Usnea angulata is characterized by a pendulous thallus and typically alate branches (Fig. 4A), with enlarged and trapezoidal segments, especially at ramifications of branches or fibrils. Soralia are minute to large, slightly stipitate, circular and well-delimitated even when crowded, while keeping a cortical margin (Fig. 4D), with few to numerous isidiomorphs. The cortex is shiny in section, the medulla thin and compact (Fig. 4E) and the axis thick (up to $80 \%$ ), with an $\mathrm{A} / \mathrm{M}$ ratio $>2$ (Fig. 1 ).

Variation. Usually pendulous with a single trunk, entangled thalli are rarely encountered. The abundance of soralia and isidiomorphs is variable and soralia may enlarge almost to the branch diameter, becoming slightly elongated. Variation of CMA values is rather large among specimens, particularly in the thickness of the medulla. However, the A/M ratio remains $>2$ (Fig. 1). Norstictic acid is the main chemotype in South America, but stictic acid or distinctive patterns of unidentified triterpenoids (Fig. 2) were also detected (Table 2). Caperatic acid, which was identified as a diagnostic character in Asiatic specimens by Ohmura (2001), was not detected in our TLC analyses. Four specimens had both soralia and lateral apothecia. A deeper taxonomic treatment with molecular studies is needed to determine if $U$. alata, the non-sorediate counterpart of $U$. angulata, belongs to the same taxon.

We observed a particularly large variation in the shape of branch segments (Fig. 4AC): specimens may exhibit weakly alate branches, looking mostly ridged or crenulate, but usually keeping trapezoidal segments at ramifications. In other specimens, the cortex surface was strongly desquamating along longitudinal and annular fissures, giving a squamulose aspect to the branch. Intermediate forms were common, especially in Andean specimens, and the shape of branch segments could not be correlated with other morphological or chemical characters. We consider these specimens as part of the infra-specific variation of $U$. angulata for the moment, but it is possible that several species hide within this taxon.

\section{Differentiation. See under U. crenulata and U. transitoria.}

Ecology. Relatively open sites within forest (mountain cloud forests, evergreen low montane forests, semi-deciduous and deciduous forests, coastal and riparian forests, Araucaria woods, secondary forests) or in the vicinity of the forest, shrubby matorral, cerrado, mangrove, isolated broadleaf or coniferous trees in pastures; primarily corticolous, occasionally saxicolous or lignicolous. This species is found at a very broad altitudinal range, from the seashore to above the treeline.

Distribution. Tropical Andes and Brazil; worldwide temperate to subtropical species also occurring in North America, Africa, 


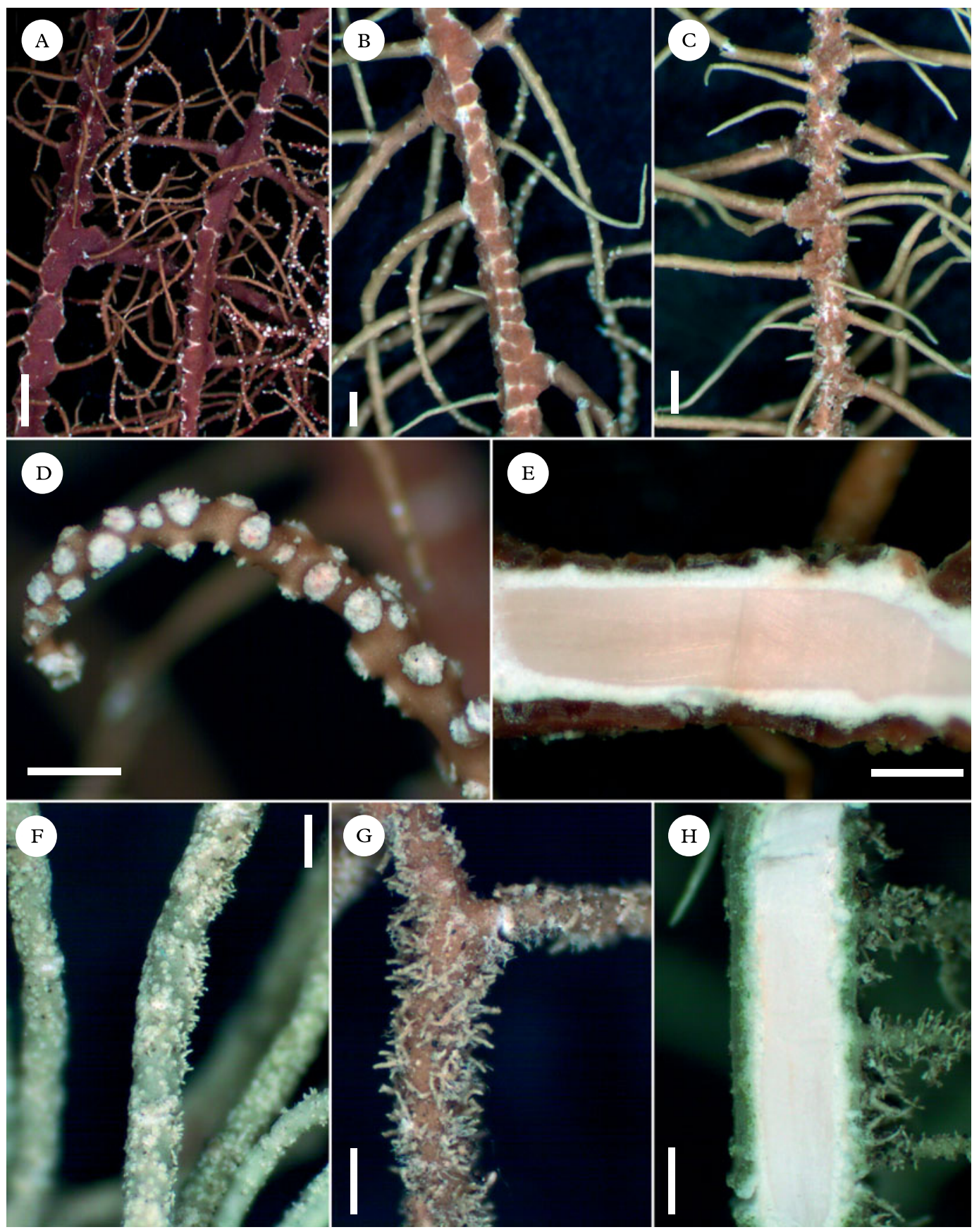

FIG. 4. A-E, Usnea angulata; A, branches strongly alate (Kalb $\mathcal{G}$ Plöbst); B, branches ridged to slightly alate (Hale 44088); C, branches squamulose with desquamating cortex (Hale 44223); D, soralia stipitate, well-delimited with a thin cortical margin (Kalb \& Plöbst); E, section of branch (Kalb E Plöbst). F-H, Usnea perhispidella; F, branches irregular, covered by minute soralia (Truong 3292); G, isidiofibrils abundantly covering the branches (Sipman 23577); H, section of branch (Truong 3292). Scales $=500 \mu \mathrm{m}$. In colour online. 
East Asia and Oceania. This species is probably extinct in the Galapagos: two herbarium specimens were collected in the $1960 \mathrm{~s}-70 \mathrm{~s}$ in a locality that is today highly disturbed by human activities. Despite the extensive sampling, $U$. angulata has not been found again in the archipelago.

Selected specimens examined. Bolivia: Cochabamba: Ayopaya, comunidad de Saila Pata, 3050 m, 1997, Bach E Fimenez 895 (B). La Paz: Basin of Rio Bopi, San Bartolome, 750 m, 1939, Krukoff 10143 (US). Santa Cruz: Florida, refugio Los Volcanes, $1000 \mathrm{~m}$, 1997, Bach et al. 634 (B)._-Brazil: Minas Gerais: Serra do Espinhaço, bei der Stadt Diamantina, 1450 m, 1978, Kalb \& Plöbst (private hb.). Rio de faneiro: Serra da Mantiqueira, Itatiaia, zwischen Registro do Picú und Agulhas Negras, 1978, Kalb \& Plöbst (private hb.). Rio Grande do Sul: Vacaria, Fazenda da Estrela, margem do rio Frade, $860 \mathrm{~m}, 2007$, Spielmann 4815 (SP). São Paulo: Ilha Comprida, near road to Cananeia ferry, $0 \mathrm{~m}$, 1979, Sipman 14149 (B)._Colombia: Antioquia: vicinity of Medellin, 1911, Charetier 169 (US). Huila: P.N. Cueva de los Guácharos, cerca de la Cueva del Indio, 2000 m, 1972, Cleef $\mathcal{E}$ van der Hammen 5102 (B).Ecuador: Galápagos: Santa Cruz, between Bella Vista and Santa Rosa, 1971, Weber (COLO).-Paraguay: Gran Chaco: Zwischen B. Aceval und Algarrobo, 150 m, 1980, Kalb (private hb.).-Peru: Cajamarca: P.N. Cutervo, cerca de San Andres de Cutervo, $2541 \mathrm{~m}$, 2007, Truong 1615 (G). Cusco: Santuario histórico de Machu Picchu, ruinas de Intipata, $2728 \mathrm{~m}, 2007$, Truong 690 (G). San Martin: Zepelacio near Moyobamba, 1100 m, 1934, Klug 3681 (US).-Venezuela: Anzoategui: along headwaters of Quebrada Tigre and Cerro Peonia, Cerro Los Pajaritos, 1500 m, 1945, Steyermark 61651 (US). Aragua: Cordillera de la Costa, cerca de Tovar, 2200 m, 1979, Vareschi 9780 (H). Distrito Federal: south slope of Cerro Avila, 1500 m, 1939, Vogt (US). Lara: Distr. Morán, bordeando a las cabeceras del río Tocuyo, 1900 m, 1974, Steyermark E Carreño Espinoza 111080 (US). Merida: between La Carbonera and El Pedregel, 2100 m, 1975, Hale E Lopez Figueiras 44232 (US). Santander del Norte: Slopes of Pico Banberas, west of Betania, páramo de Tama, $2400 \mathrm{~m}, 1975$, Hale E Lopez-Figueiras 45799 (US). Tachira: Via Villa PaezBetania, valley of páramo de Tama, 2000 m, 1975, Hale $\mathcal{G}$ Lopez-Figueiras 45205 (US).

\section{Usnea arthroclada Fée}

Essai Crypt. Exot. (Paris): 148, tab. 111, fig. 4 (1825) ['1824']; type: Brazil [collector unknown] (G!-holotype, $\mathrm{P}$-possible isotype). \% C/M/A: 4/33.5/24.5. Chemistry: usnic, stictic, constictic, menegazziaic, traces of norstictic acids.

Usnea superba Motyka syn. nov., Lich. Gen. Usnea Stud. Monogr. Pars Sys. 2: 628 (1938); type: Brazil, Minas, Passo Quarto, 1921, Zikan (W!- holotype; LBL!, S!isotypes). \% C/M/A: 7.5/34.5/16. Chemistry: usnic, stictic, constictic, menegazziaic, traces of norstictic acids.

\section{(Fig. $3 \mathrm{~F}-\mathrm{H}$ )}

Thallus subpendulous to pendulous, rarely entangled, to more than $30 \mathrm{~cm}$ long, with a smooth and pruinose cortex surface; ramifications mostly anisotomic-dichotomous, becoming isotomic-dichotomous towards the apices; trunk single or several attachment points, concolorous with the branches, not to distinctly annulated; branches slightly to strongly irregular, regularly segmented from the base to the apices (Fig. 3F), with annulations often eroded at edges (whitish) and with a \pm dented margin (Fig. 3G), rarely with areas of regenerative cortex forming in between segments; branch segments terete to slightly flattened, not to slightly inflated (rarely strongly inflated or 'sausage-like') especially on basal branches; lateral branches not to slightly constricted at ramification; foveoles absent to scattered on basal branches; maculae whitish, minute to \pm irregular in shape, conspicuously spotting the cortex surface of branches (Fig. 3G) or aggregating in irregular clusters; pseudocyphellae few and inconspicuous (opening maculae); papillae and tubercles absent; fibrils absent or few and irregularly dispersed on terminal branches (young branches?); fibercles absent; soralia absent; cortex thin to moderately thin (5.0$7.5 \%)$, matt in section; medulla thick (28.0$34.5 \%$ ), dense, looser towards the axis (Fig. $3 \mathrm{H})$; axis thin (19-30\%), often pinkish, with an $\mathrm{A} / \mathrm{M}$ ratio $<1 \cdot 25$ (Fig. 1 ).

Apothecia serial, rarely sub-terminal, with long cilia turning into segmented branches.

Pycinidia globose on lateral branches.

Diagnostic notes. Usnea arthroclada is a nonsorediate species (usually with lateral apothecia), characterized by branches segmented into terete to slightly inflated segments, with annulations that are eroded at edges. The cortex surface of branches is distinctly pruinose and maculate. The cortex is matt and the medulla dense, reacting $\mathrm{K}+$ yellow (stictic acid, Table 2), with an $\mathrm{A} / \mathrm{M}$ ratio $<1.25$ (Fig. 1).

Variation. The degree of inflation of branches, as well as the abundance of maculae and foveoles, may vary among specimens. 
Thalli are usually subpendulous to pendulous, with a single, distinctly annulated trunk, but entangled thalli may occur.

Differentiation. Usnea amabilis is occasionally fertile and differs in the presence of minute pseudocyphellae on main branches (absent or never abundant in U. arthroclada) and a cortex surface without maculae or only faintly maculate. Both species also have distinct chemotypes (Table 2) and a different geographical distribution in South America, $U$. amabilis being so far endemic to the Andes, whereas $U$. arthroclada occurs in Brazil.

Ecology. Relatively open places within broadleaf or coniferous forests, or in the vicinity of the forest; corticolous.

Distribution. Brazil; also reported from Ecuador and Central America (Motyka 1936).

Selected specimens examined. Brazil: Minas Gerais: Serra da Mantiqueira, Fazenda São Mateus östlich von Camanducaia, 1800 m, 1980, Kalb (private hb.). Rio de faneiro: Serra do Mar, zwischen Paratí und Cunha, 1979, Kalb \& Plöbst (private hb.). Sao Paulo: Serra da Bocaina, 1952, Mattick 16151a (B).-Costa Rica: San fosé: Cerro Zurqui, 1500-1600 m, 1929, Dodge (LBL).

\section{Usnea articulata (L.) Hoffm.}

Deutschl. Fl. 2: 133 (1796); type: England, Burnley (OXF-lectotype). Chemistry: usnic, protocetraric, traces of fumarprotocetraric acids (Swinscow \& Krog 1976).

Usnea venusta Motyka syn. nov., Lich. Gen. Usnea Stud. Monogr. Pars Sys. 2: 441 (1938); type: Brazil, Sta Catharina, Serra do Oratorio, 1890, Ule (S!-lectotype selected here; LBL! -isolectotype). \% C/M/A: 2/43.5/

9. Chemistry: usnic, salazinic and norstictic acids.

Nomenclatural notes. Motyka (1938) indicated that the holotype of $U$. venusta was deposited in $\mathrm{B}$, but this specimen appears to be missing. We found one isotype deposited in $\mathrm{S}$ and designated it as the lectotype, while another isotype deposited in LBL was considered as isolectotype.

\section{(Fig. 5A-C)}

Diagnostic notes. A detailed description is available in Swinscow \& Krog (1976). This species is readily distinguished by the lax thallus, due to the thin cortex $(<2.5 \%)$, shiny in section, the large $(>42 \%)$ and lax medulla (Fig. 5C) and the thin axis $(<10 \cdot 5 \%$ ), with an $\mathrm{A} / \mathrm{M}$ ratio $<0.25$ (Fig.
1). Branches are segmented in distinctly swollen segments (fusiform), constricted at ramification along basal branches (Fig. 5A). Soralia are absent but punctiform pseudocyphellae are sparsely distributed on the branches (Fig. 5B). The chemotype of salazinic acid, which was already reported from African specimens (Swinscow \& Krog 1976), was detected in South America (Table 2).

Variation. Apothecia are present or not. Swinscow \& Krog (1976) mention that the abundance of pseudocyphellae may vary among specimens and that pseudocyphellae may produce abundant isidiomorphs, but South American specimens had sparse pseudocyphellae and isidiomorphs.

Differentiation. Usnea deformis shares the lax thallus with inflated branch segments and very thin cortex and axis, but branches are strongly deformed and soralia are abundantly present, enlarging almost to the branch diameter or aggregating in irregular clusters, looking like large soralia.

Ecology. Coniferous forests; corticolous on Araucaria or Podocarpus.

Distribution. Brazil, rare $(n=2)$; previously reported from Europe, Africa, Asia and Australia (Swinscow \& Krog 1976; Stevens 1999).

Selected specimens examined. Brazil: São Paulo: Serra da Bocaina, 1952, Mattick 16179 (B).

\section{Usnea crenulata Truong $\& P$. Clerc sp. nov.}

\section{MycoBank No.: MB 800747}

Thallus pendulous to entangled, branches ridged with eroded cortex, soralia minute and crowded, medulla very thin, reacting $\mathrm{K}-$ (triterpenoids).

Type: Venezuela, Merida, between La Carbonera and El Pedregal, small isolated trees in a rocky pasture, 2100 m, 1975, Hale E Lopez Figueiras 44237 (US-holotype; G-isotype). \% C/M/A: 8/9/66.5. Chemistry: usnic acid and unidentified triterpenoids.

(Fig. 6A-E)

Thallus pendulous to entangled, to more than $100 \mathrm{~cm}$ long, with few ramifications and long parallel branches; ramifications \pm anisotomic-dichotomous; trunk concolorous 


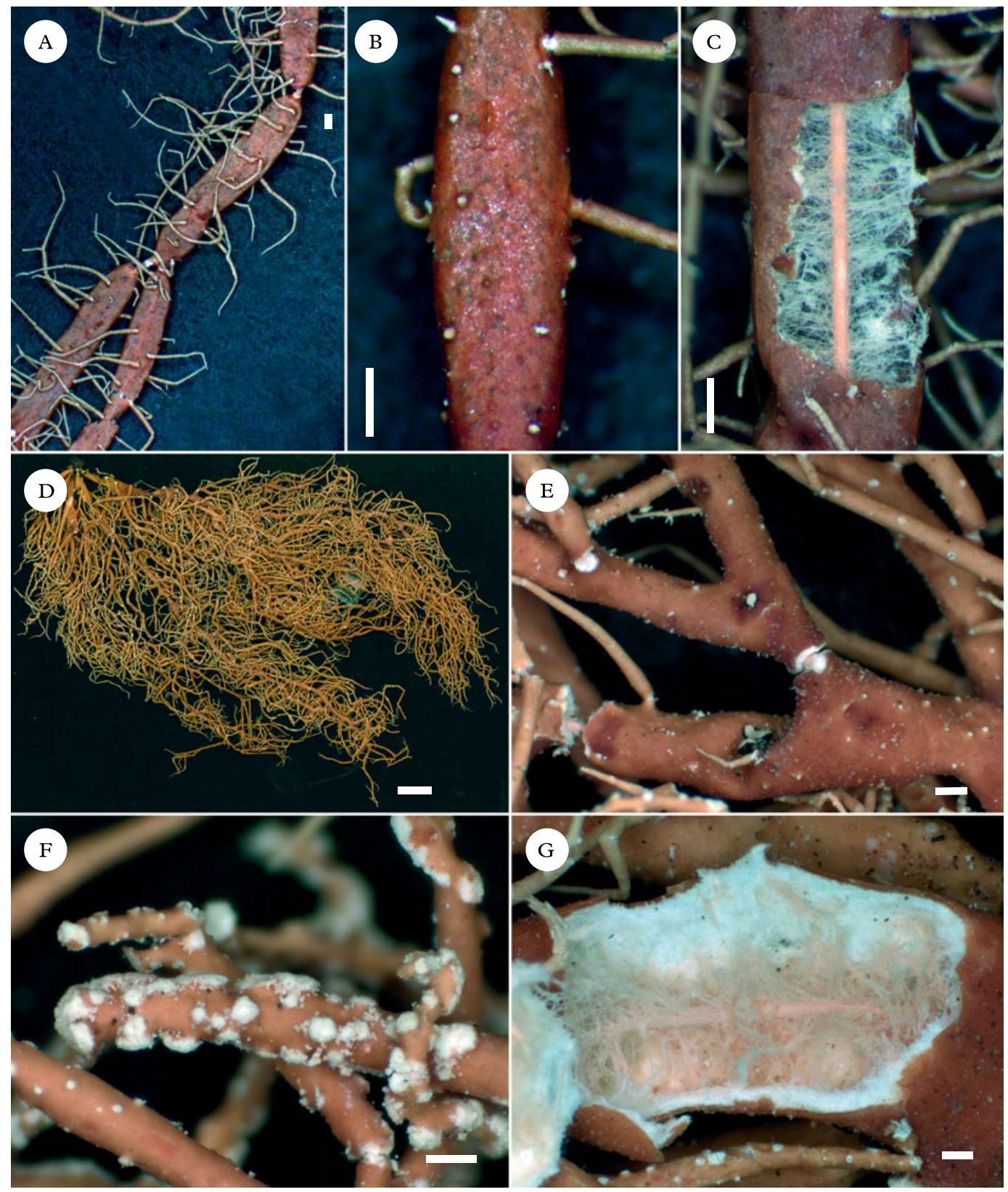

FIG. 5. A-C, Usnea articulata (lectotype of U. venusta); A, swollen branches constricted at ramifications (fusiform); B, punctiform pseudocyphellae sparsely distributed on the branches; C, section of branch. D-G, Usnea deformis (Aguirre E Sipman 5810); D, fragile thallus; E, basal branches strongly deformed, with numerous foveoles; F, soralia aggregating in irregular clusters on lateral/terminal branches; $\mathrm{G}$, section of branch. Scales: A-C, E-G $=500 \mu \mathrm{m}$; $\mathrm{D}=10 \mathrm{~mm}$. In colour online. 


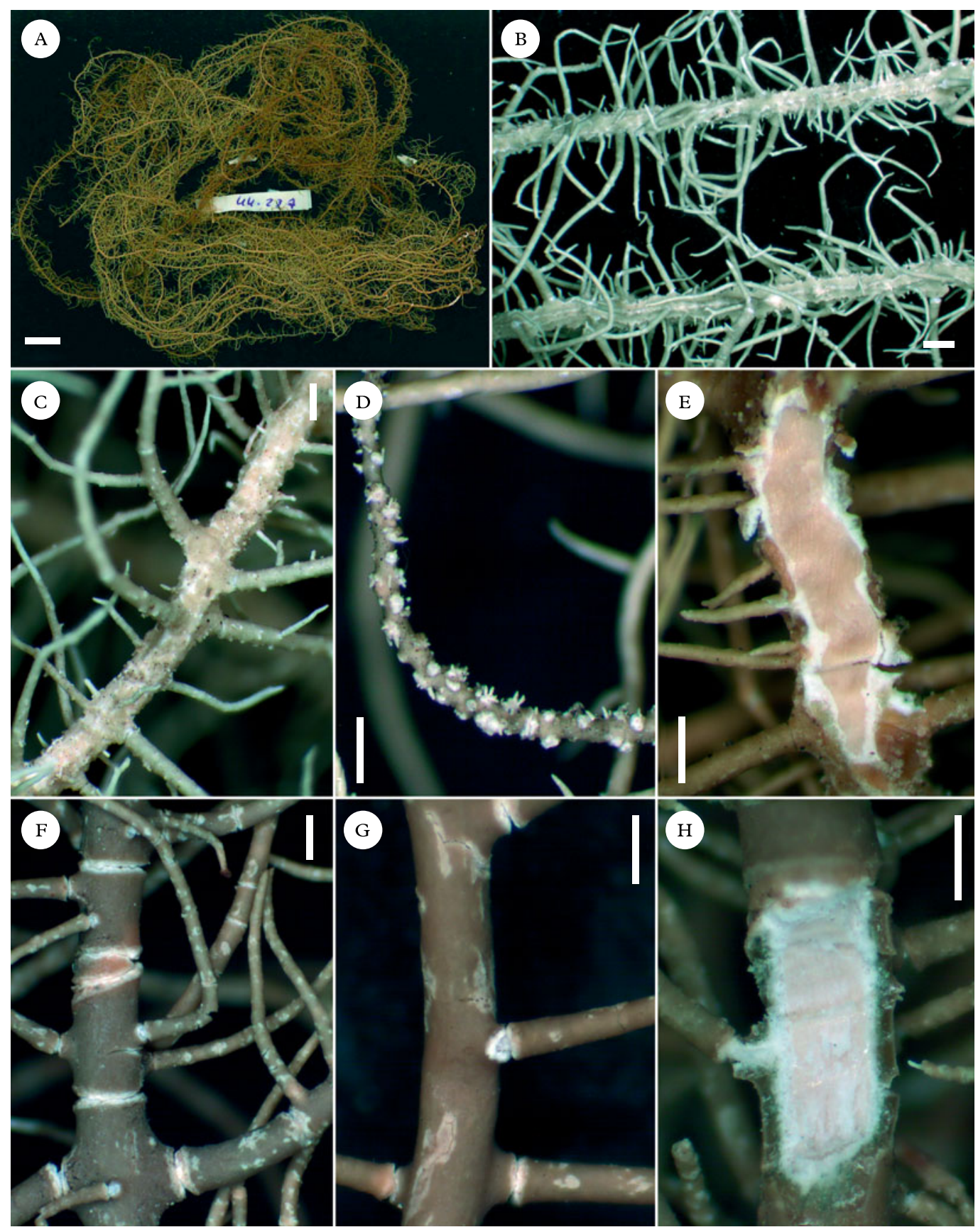

FIG. 6. A-E, Usnea crenulata; A, holotype; B, branches with ridged segments (Truong 1673); C, cortex eroding along longitudinal and transverse fissures (Truong 1663); D, minute soralia aggregating on lateral branches, without a cortical margin; isidiomorphs numerous (Sipman et al. 23669); E, section of branch (Lopez-Figueiras $\mathcal{E}$ Keogh 9249). F-H, Usnea malmei (Lopez-Figueiras 17150); F, branches segmented by large annular cracks with eroded edges and bead-like cortical regenerations in between segments; G, conspicuous elongated pseudocyphellae; H, section of branch. Scales: $\mathrm{A}=1 \mathrm{~cm} ; \mathrm{B}-\mathrm{H}=500 \mu \mathrm{m}$. In colour online. 
with the branches, often with numerous hapters; branches cylindrical, tapering only at the apices; branch segments ridged (Fig. 6B); lateral branches not to slightly trapezoidal atramification; foveoles absent; maculae absent or faint on lateral branches and fibrils, sometimes opening as pseudocyphellae; $p a-$ pillae and tubercles absent or scattered on basal branches; fibrils numerous, slender, distributed in a rather dense fishbone pattern; soralia minute, developing from the cortex ad initio, slightly stipitate, becoming convex at maturity, often crowded and aggregating on lateral branches, without a cortical margin (Fig. 6D); isidiomorphs short, often numerous; cortex shiny in section, moderately thick to thick $(8 \cdot 0-12 \cdot 5 \%)$, cortex surface eroding along fissures of branches (Fig. 6C), rarely almost desquamating; medulla very thin (3.5$6 \cdot 5 \%$ ) and compact (Fig. 6E); axis thick (63.0-75.5\%), often faint to dark pink, with an $\mathrm{A} / \mathrm{M}$ ratio $>5$ (Fig. 1).

Apothecia and pycnidia not seen.

Diagnostic notes. Usnea crenulata is characterized by a pendulous to entangled thallus (several inconspicuous hapters) with ridged branches and the cortex surface eroding along fissures of branches. Soralia are minute and crowded on lateral branches, without a cortical margin, capitate at maturity, with numerous isidiomorphs. The medulla is very thin, reacting $\mathrm{K}-$, with a pattern of unidentified triterpenoids that is characteristic of this species (Fig. 2). The axis is one of the largest among the species studied here, with an $\mathrm{A} / \mathrm{M}$ ratio $>5$.

Variation. Segments of main branches are slightly to strongly ridged, rarely almost squamulose when the cortex is desquamating. Basal branches tend to be more distinctly ridged than terminal branches. Cortex thickness is variable along the branch in correlation to its degree of erosion or desquamation, but it is usually thick on the areas where it remains entire.

Differentiation. Specimens with strongly ridged branches and desquamating cortex can be difficult to separate from squamulose specimens of $U$. angulata, but the latter has well-delimited soralia with a distinct cortical margin and the presence of norstictic acid or other patterns of triterpenoids in the medulla (Fig. 2). Usnea angulata also tends to have a thicker medulla, although these values overlap between the two species due to the large variation observed in U. angulata (Fig. 1). Usnea transitoria has similar CMA values to $U$. crenulata, but differs in the presence of abundant tubercles covering the branches, large and delimited bands of eroding cortex along main branches and a $\mathrm{K}+$ medulla.

Ecology. Primary and disturbed mountain cloud forests (including Ceroxylon or Podocarpus spp.) or open places in the vicinity of the forest, such as deforested zones of matorral or isolated trees in pastures; corticolous.

Distribution. So far endemic to the tropical Andes.

Selected specimens examined. Bolivia: Cochabamba: 5 km al sur de Saila Pata, 3050 m, 1997, Bach E Fimenez 863 (B).-Colombia: Cundinamarca: San Francisco, vereda Sabaneta, 2500 m, 1986, Sipman 23581 (B). Huila: La Plata, volcan Merenberg, 2600 m, 1984, Aguirre E Sipman 5842 (B).-CPeru: Cajamarca: Ruinas de Kuelap, 3100 m, 2007, Truong 1854 (G). Pasco: P.N. Yanachaga-Chemillén, trocha hasta la ambra Esperanza, 2419 m, 2007, Truong 2474 (G).-Venezuela: Merida: La Carbonera, 2400 m, 1974, Hale 42065 (US). Tachira: slopes of Pico Banberas, páramo de Tama, 2600 m, 1975, Hale E Lopez-Figueiras 45415 (US).

\section{Usnea deformis Motyka}

Lich. Gen. Usnea Stud. Monogr. Pars Sys. 2: 488 (1938); type: Mexico, Santa Barbara près Puebla, 1910, Nicolas (LBL!-holotype; isotypes W!-isotype). \% C/M/A: $1 \cdot 5 / 37 / 23$. Chemistry: usnic, stictic, constictic, menegazziaic, traces of norstictic acids.

\section{(Fig. 5D-G)}

Thallus primarily subpendulous, rarely erectshrubby, very fragile, to $c .20 \mathrm{~cm}$ long; ramifications mostly anisotomic-dichotomous; trunk concolorous with the branches; branches irregular and strongly deformed (Fig. 5E), segmented into \pm swollen segments; lateral branches slightly to distinctly constricted at ramification, at least on basal branches; foveoles abundant and very conspicuous on main branches (Fig. 5E); maculae and pseudocyphellae absent; papillae absent or sparse 
(indistinct low bumps); fibrils slender, scattered to numerous and irregularly distributed; soralia arising from the cortex ad initio, plane to slightly stipitate, capitate at maturity, often very crowded and confluent on lateral/terminal branches, then resembling a single large soralium (Fig. 5F) or enlarging almost to the branch diameter; isidiomorphs few to numerous, sometimes growing into isidiofibrils; cortex shiny in section, thin (3.0$4.5 \%)$; medulla large (37.5-42.5\%), lax, denser towards the cortex (Fig. 5G), sometimes with transverse bundles of hyphae between the cortex and the axis; axis thin (8.5$17 \cdot 0 \%$ ), with an $\mathrm{A} / \mathrm{M}$ ratio $<0.5$ (Fig. 1 ).

Apothecia rare $(n=1)$.

Pycnidia not seen.

Diagnostic notes. The very fragile thallus (thin cortex and axis), the deformed branches, constricted at ramifications with inflated segments and conspicuous foveoles, and the presence of abundant soralia with isidiomorphs readily distinguish this species.

Variation. This species varies in the abundance of papillae, fibrils, isidiomorphs (occasionally growing into isidiofibrils) and soralia. Soralia may remain minute, enlarge almost to the branch diameter or aggregate in irregular clusters. Three chemotypes were detected in South America (Table 2).

The type specimen of $U$. deformis (collected in Mexico) is irregularly covered with a dense array of thick and spinulous fibrils on restricted areas on the branches. Such fibrils were not observed in South American specimens, but could possibly be the result of infestation by parasitic fungi. We prefer to use the name of $U$. deformis for the moment, but the study of further material from Central America is needed to see if it corresponds to South American material.

Differentiation. See under $U$. articulata. In $U$. dimorpha, basal branches are also \pm deformed and inflated, but the thallus is stiff, due to the thicker cortex and axis, with a thinner and denser medulla. In addition, fibrils are abundantly distributed in a fishbone pattern and eroded tubercles are often present on the branches.
Ecology. Open sites within montane cloud forests or in the vicinity of the forest, deforested zones of matorral, isolated trees in pastures, páramo up to relatively high altitudes; corticolous.

Distribution. Tropical Andes; previously reported from Mexico and California (Motyka 1936).

Selected specimens examined. Bolivia: Cochabamba: P. N. Carrasco, Sehuencas, río Fuertemayu, $2183 \mathrm{~m}$, 2007, Truong 3103 (G).-Colombia: Huila: La Plata, headwaters of Rio La Candelaria, 2300 m, 1984, Aguirre E Sipman 6174 (B). Tolima: Santa Isabel, margen del río Totarito, $3730 \mathrm{~m}, 1980$, Valencia $\mathcal{E}$ Boekhout 55 (B).-Peru: Cajamarca: P. N. Cutervo, cerca de San Andres de Cutervo, 2665 m, 2007, Truong 1635 (G). Cusco: Santuario histórico de Machu Picchu, abra Runkuraquay, 3809 m, 2007, Truong 2010 (G).Venezuela: Merida: Distr. Liberador, pico Espejo, Loma Redonda, 4200 m, 1989, Kalb (private hb.). Tachira: Páramo La Negra, 3100 m, Vareschi 3975 (LBL).

\section{Usnea dimorpha (Müll. Arg.) Motyka}

Lich. Gen. Usnea Stud. Monogr. Pars Sys. 2: 460 (1938).-Usnea articulata var. dimorpha Müll. Arg., Flora LXXIV: 372 (1891); type: Cuba, Pinal de Sta Ana, Eggers 5015 (G!-holotype). \% C/M/A: 5/35/20 (higher branch, base lacking). Chemistry: usnic, norstictic, galbinic and salazinic acids.

\section{(Fig. 7A-C)}

Thallus subpendulous to pendulous, to more than $50 \mathrm{~cm}$ long; ramifications distinctly anisotomic-dichotomous; trunk concolorous with the branches, often with a reddish tinge, sometimes with thin annulations; branches irregular, with \pm strongly deformed segments (basal branches), slightly flattened, ridged or inflated (Fig. 7A); lateral branches not to slightly constricted at ramification; foveoles often numerous, conspicuous on basal branches (Fig. 7A); maculae and pseudocyphellae absent; papillae absent or sparse (indistinct low bumps); tubercles scarce to abundant, minute, eroded on top; fibrils slender, \pm regularly distributed in fishbone pattern; fibercles often present but scarce; soralia growing from the cortex ad initio or from tubercles, slightly stipitate, capitate at maturity, often very crowded and aggregating on terminal/lateral branches or fibrils (Fig. 7B), rarely encircling thin terminal 


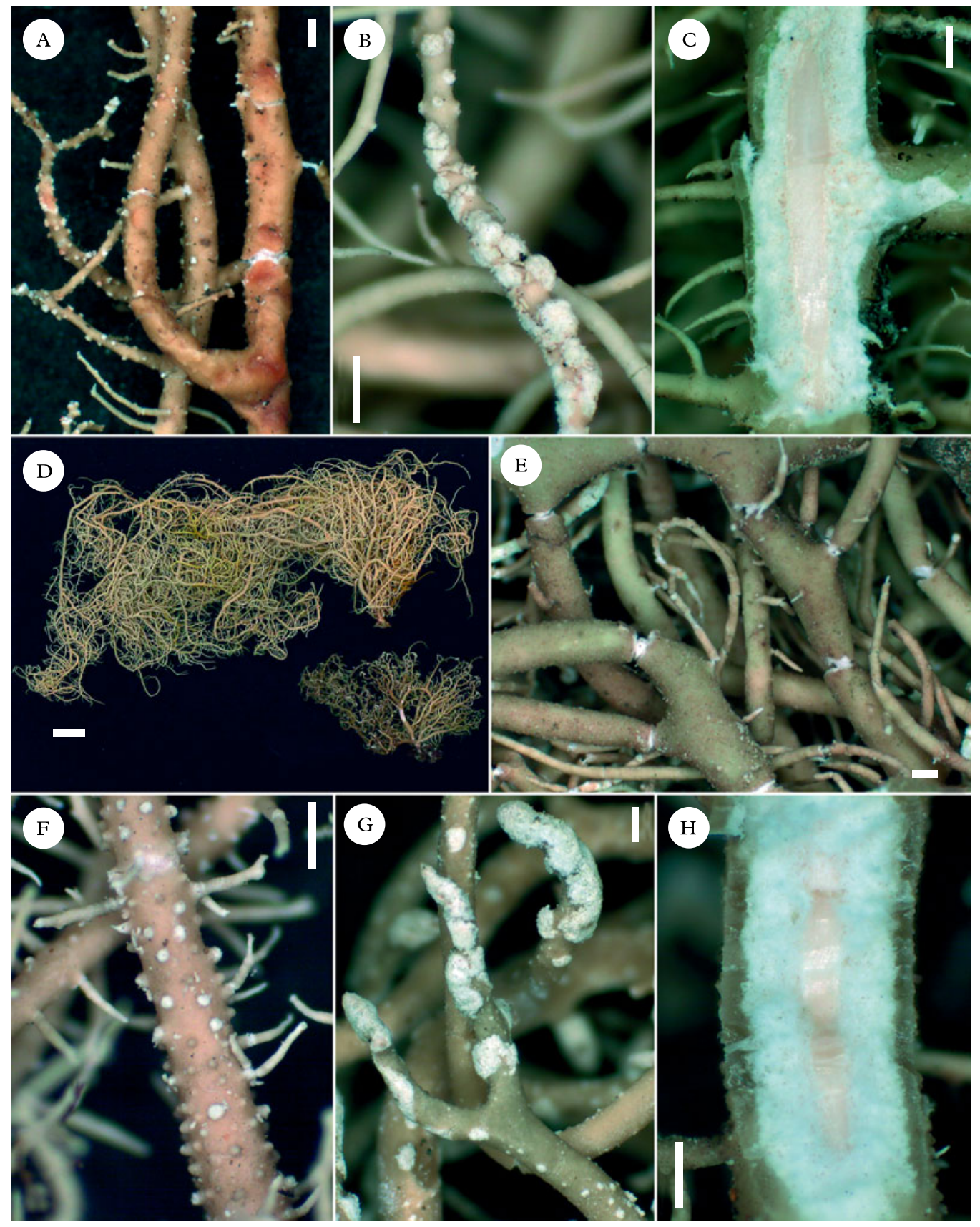

Fig. 7. A-C, Usnea dimorpha; A, basal branches deformed, with abundant foveoles (Aguirre E Sipman 5729); B, soralia capitate, aggregating on terminal/lateral branches or fibrils (Truong 703); C, section of branch (Truong 703). D-H, Usnea dodgei; D, short erect-shrubby or long subpendulous thalli (Aptroot 65133, 65704); E, branches inflated and constricted at ramification (Clerc 08-80); F, tubercles abundant, eroded on top (Aguirre E Sipman 6173); $\mathrm{G}$, soralia fusing to cover the apices of branches (Bungartz 4356); H, section of branch (Aptroot 65704). Scales: $\mathrm{A}-\mathrm{C} \& \mathrm{E}-\mathrm{H}=500 \mu \mathrm{m} ; \mathrm{D}=1 \mathrm{~cm}$. In colour online. 
branches; isidiomorphs small, often numerous; cortex shiny in section, thin to moderately thin (4.5-7.0\%); medulla dense (Fig. 7C), moderately thick to thick $(25 \cdot 5-32 \cdot 0 \%)$, with a faint pink to orange periaxial pigmentation; axis thin to moderately thin (26-37\%), sometimes faintly pinkish, rarely fistulose on basal branches.

\section{Apothecia and pycnidia not seen.}

Diagnostic notes. This species is characterized by the stiff thallus with deformed basal branches, conspicuous foveoles and abundant fibrils. Soralia are crowded on terminal/lateral branches and fibrils, becoming capitate at maturity. The medulla is dense, reacting $\mathrm{K}+$ yellow turning red (galbinic acid, Table 2).

Variation. The degree of deformation of basal branches as well as the abundance of foveoles, papillae and tubercles may vary among specimens.

Differentiation. See under $U$. deformis and U. dodgei.

Ecology. Relatively open sites within forest (primary and disturbed montane cloud forests to the upper treeline, Quercus woods) or in the vicinity of the forest, páramo, deforested zones of matorral, isolated trees in pastures; primarily corticolous, occurring occasionally on rocks or clay walls.

Distribution. Tropical Andes and Brazil; previously reported from the Caribbean and Florida (Motyka 1936; Moore 1968).

Selected specimens examined. Brazil: Rio Grande do Sul: Sinimbu, Cava Funda, 500 m, 2004, Spielmann 981 (SP).-Colombia: Cundinamarca: San Francisco, near Quebrada Cueva Grande, 2500 m, 1986, Sipman 23582 (B). Huila: La Plata, finca Merenberg, $2400 \mathrm{~m}, 1984$, Aguirre E Sipman 5729 (B). Nariño: Pasto, km 16 Pasto-Chachagüi, 2640 m, 1991, Ramírez 3227 (B).Ecuador: Imbabura: Reserva ecológica CotacachiCayapas, laguna Cuicotcha, islote Verovi, $3093 \mathrm{~m}$, 2007, Truong 784 (G). Pichincha: Reserva geobotánica Pululahua, valle en la base del cráter, $2467 \mathrm{~m}, 2007$, Truong 3367 (G).-Peru: Cajamarca: San Pablo de Valera, camino a la catarata Gocta, 2043 m, 2007, Truong 1819 (G). Cusco: Santuario histórico de Machu Picchu, ruinas de Intipata, $2728 \mathrm{~m}, 2007$, Truong 703 (G).Venezuela: Merida: Distr. Rangel, zwischen der laguna Mucubaji und dem pico Mucuñuque, 3500 m, 1989, Kalb (private hb.). Tachira: slopes of Pico Banberas, páramo de Tama, 2600 m, 1975, Hale $\mathcal{E}$ Lopez-Figueiras 45241 (US).

\section{Usnea dodgei Motyka}

Lich. Gen. Usnea Stud. Monogr. Pars Sys. 2: 610 (1938); type: Costa Rica, Cartago, pr. Naranjo, 1875, Polakowsky (LBL! - holotype; S! —isotype). \% C/M/A: 7.5/30/ 24.5. Chemistry: usnic, stictic, constictic, menegazziaic, traces of norstictic acids, unidentified triterpenoids.

\section{(Fig. 7D-H)}

Thallus primarily subpendulous or erectshrubby, to $c .15 \mathrm{~cm}$ long; ramifications mostly anisotomic-dichotomous; trunk concolorous with the branches, often with thin annulations; branches irregular, with terete to slightly angular segments, slightly to strongly inflated (Fig. 7E); lateral branches not to distinctly constricted at ramification; foveoles absent or scarce; maculae and pseudocyphellae absent; papillae few to abundant, hemispherical to verrucose, giving a rugose aspect to the cortex surface; tubercles few to abundant, minute to slightly elongated, later eroded on top (Fig. 7F) and sometimes enlarging into distinctly stipitate soralia; fibrils slender, scattered to numerous; fibercles absent or scarce; soralia arising from tubercles, minute and stipitate on basal and secondary branches, becoming large and plane on terminal branches (rarely remaining stipitate), typically fusing to cover the apices of branches (Fig. 7G); isidiomorphs short, few to very abundant; cortex shiny in section, moderately thin to thick (7-11\%); medulla dense (Fig. $7 \mathrm{H}$ ), moderately thin to thick $(21 \cdot 5-31.5 \%)$; axis thin to moderately thin $(20 \cdot 5-40 \cdot 0 \%)$, often with a faint pink pigmentation, rarely fistulose on basal branches, with an $\mathrm{A} / \mathrm{M}$ ratio of $0 \cdot 5-2 \cdot 0$ (Fig. 1).

Apothecia rare $(n=3)$.

Pycnidia not seen.

Diagnostic notes. The branches with slightly inflated segments, not to distinctly constricted at ramification, the numerous papillae and tubercles on the cortex surface of main branches, and the shiny and relatively thick cortex distinguish this species. Soralia are minute and stipitate at young stage, becoming plane and fusing to cover the apices of branches at maturity.

Variation. Short erect-shrubby or long subpendulous thalli occur in this species (Fig. 7D). The degree of inflation of branches 
varies in correlation with the density of the medulla and the $\mathrm{A} / \mathrm{M}$ ratio. Although tubercles are usually abundant, several specimens exhibited branches with a rugose cortex surface but scarce tubercles. Soralia are sometimes very abundant, both on secondary and terminal branches, whereas in other specimens they are predominantly distributed on terminal branches; in that case they are mostly plane, fusing to cover the apices of branches. Soralia remain typically stipitate on main and secondary branches and rarely on terminal branches as well. Three chemotypes were detected (Table 2), all including the same pattern of unidentified triterpenoids (Fig. 2) which is characteristic of this species.

Differentiation. Usnea dimorpha differs in the irregular branches with deformed segments, the capitate soralia, a thinner cortex and the absence of triterpenoids in the medulla. Papillae and tubercles are also present but usually not as abundantly as in $U$. dodgei.

Ecology. Relatively open sites within forest (tropical rainforests, montane cloud forests, Quercus woods) or in the vicinity of the forest, cerrado, deforested zones of matorral, isolated trees in pastures; in the Galapagos, from the arid to the humid zone, most abundant in the transition zone. Primarily corticolous, occasionally saxicolous or lignicolous.

Distribution. Brazil, Tropical Andes and the Galapagos; reported also from Costa Rica (Motyka 1936).

Selected specimens examined. Brazil: Minas Gerais: Fazenda São Mateus östlich von Camanducaia, 1800 m, 1980, Kalb (private hb.). São Paulo: Parque estadual da Serra do Mar, Nucleo Santa Virginia, 920 m, 2007, Spielmann 3178 (SP)._Colombia: Cauca: Silvia, c. 30 $\mathrm{km}$ NE of Popayan, 2300 m, 1986, Sipman 33807 (B). Cundinamarca: Tena, laguna de Pedro Palo, 2000 m, 1984, Aguirre E Sipman 5640 (B). Huila: La Plata, headwaters of río La Candelaria, 2300 m, 1984, Aguirre $\mathcal{E}$ Sipman 6173 (B). Nariño: Munic. Pasto, along main road to Popayan, c. $2 \mathrm{~km}$ beyond toll barrier, $2550 \mathrm{~m}$, 1986, Sipman et al. 33639 (B). Risaralda: Munic. Pereira, a lo largo del río Otún, 3000m, 1980, Aguirre Eீ Gradstein 1710 (B). Santander: Charala, corregimiento Virolín, 1750 m, 1988, Sipman $\mathcal{E}$ Aguirre 27490 (B).-Ecuador: Galápagos: Isabela, Volcán Alcedo, 1035 m, 2006, Aptroot 64850 (CDS); San Cristobal, trail to Ochoa, $315 \mathrm{~m}$, 2008, Truong 1429 (G); Santa Cruz, dirt road to Mina
Granillo, 547 m, 2008, Truong 1305 (G); Santiago, summit of Cerro Gavilan, 840 m, 2006, Aptroot 65704 (CDS).-Peru: Cusco: Centro de investigación Wayqecha, Trocha Wayqecha, $2887 \mathrm{~m}, 2007$, Truong 2201 (G). Pasco: P.N. Yanachaga-Chemillén, trocha hasta la ambra Esperanza, 2482 m, 2007, Truong 3874 (G).Venezuela: Distrito Federal: Caracas, Gallner (LBL). Merida: La Carbonera, Merida-La Azulita road, 2200 m, 1976, Hale 46814 (US). Tachira: Base del Cobre Chiquito, Valle del páramo de Tama, $2450 \mathrm{~m}, 1975$, Hale $\mathcal{E}$ Lopez-Figueiras 45559 (US).

\section{Usnea firma Motyka}

Lich. Gen. Usnea Stud. Monogr. Pars Sys. 2: 410 (1938); type: Brazil, Teresiopolis, Wawra (W!-holotype; LBL!isotype). \% C/M/A: 8/17/50. Chemistry: usnic and protocetraric acids (Herrera-Campos et al. 1998).

Diagnostic notes. A detailed description is available in Herrera-Campos et al. (1998). This is a non-sorediate, pendulous species (usually with apothecia), with \pm cylindrical branches tapering only at the apices and distinctly segmented with \pm thin annulations. The cortex is matt to \pm shiny and the medulla is compact, reacting $\mathrm{K}-$ (protocetraric acid, Table 2).

Variation. A very high morphological variation was observed in South American specimens and characters that have been used to differentiate this species, mainly from $U$. himantodes (syn. U. sericea), became difficult to correlate. Following the concept of HerreraCampos et al. (1998), U. firma would be the non-sorediate counterpart of $U$. subgracilis, with cylindrical branches (terete segments) segmented by thin annulations, sometimes with extruding medulla in between segments, a non-pigmented axis and a matt cortex with a smooth cortex surface. On the other hand, $U$. himantodes would be the non-sorediate counterpart of $U$. mexicana, with cylindrical to irregular branches (terete to ridged segments) segmented by thin to large annulations, with eroded edges and sometimes bead-like cortical regenerations in between segments, a pigmented axis and a matt to shiny cortex with a cracked to areolate cortex surface. When studying South American specimens, we observed a continuum of forms from a typical 'firma' morphotype to a typical 'himantodes' morphotype. In particular, numerous specimens had a non- 
pigmented central axis, but otherwise sharing the morphology of $U$. himantodes. The type specimen of $U$. firma itself has a nonpigmented axis, but a \pm shiny cortex with a distinctly areolate cortex surface. None of the characters that were used to circumscribe these species (branches cylindrical or irregular, shape of branch segments, presence of bead-like cortical regenerations at annulations, cortex surface smooth or cracked, cortex matt or shiny, axis pigmentation, CMA values) happens to correlate with another, and all South American specimens share the same chemotype (protocetraric acid). These taxa are in need of a detailed revision over their whole geographical range (U. himantodes was described in Australia and $U$. sericea in Mexico), with the help of molecular tools. The occurrence of hybrids is not excluded. For the moment, we have kept all South American specimens under the South American name of U. firma.

Ecology. Relatively open sites within coniferous or broadleaf forests or in the vicinity of the forest, isolated trees along roads; corticolous.

Distribution. Brazil; previously reported from Costa Rica and Mexico as well (Motyka 1936; Herrera-Campos et al. 1998).

Selected specimens examined. Brazil: Minas Gerais: Serra da Mantiqueira, Vila Monte Verde, c. $30 \mathrm{~km}$ östlich von Camanducaia, 1978, Kalb \& Plöbst (private hb.). Rio de faneiro: P. N. da Serra dos Orgãos, near Abrigo 2, 1600 m, 1952, Mattick 345 (B). São Paulo: Serra do Mar, c. $20 \mathrm{~km}$ östlich von Cruzeiro, 1978, Kalb \& Plöbst (private hb.).

\section{Usnea geissleriana P. Clerc}

Lichenologist 38: 197 (2006); type: Spain, Canary Islands, Tenerife, forêt de Los silos [...], 980 m, 1986, Clerc 11548 (G!-holotype). \% C/M/A: 6.5/23/41. Chemistry: usnic, salazinic and norstictic acids (Clerc 2006).

\section{(Fig. 8A-C)}

Diagnostic notes. A detailed description is available in Clerc (2006). Usnea geissleriana is characterized by irregular branches (terete to slightly swollen segments), not constricted at ramification and segmented with thin annulations mostly visible along the trunk (Fig. 8A) and basal branches. The cortex surface is slightly to strongly pruinose, sometimes with faint maculae spotting the cortex surface and/or minute pseudocyphellae. Soralia are minute, rarely slightly enlarging, plane to slightly stipitate, sometimes capitate at maturity, aggregating in \pm irregular clusters on lateral/terminal branches (Fig. 8B), with short isidiomorphs. The cortex is matt in section and the medulla is dense (Fig. $8 \mathrm{C}$ ), with an $\mathrm{A} / \mathrm{M}$ ratio $<1.5$ (Fig. 1).

Variation. The degree of inflation of branch segments, as well as the abundance of maculae, pseudocyphellae, soralia and isidiomorphs, may vary among specimens. As in Macaronesia (Clerc 2006), two chemotypes were detected (stictic or salazinic acids, Table 2).

Differentation. Usnea regia and $U$. amabilis share the irregular branches and the matt cortex with a pruinose cortex surface. Usnea regia differs in the conspicuous maculae drawing a network on the cortex surface of main branches, the large and distinctly stipitate soralia, remaining well-delimited at maturity, and the compact medulla with an $\mathrm{A} / \mathrm{M}$ ratio $>1 \cdot 25$. Usnea amabilis differs in the entangled thallus with several inconspicuous hapters, scarce soralia and a different chemotype (Table 2). Usnea subflammea has abundant tubercles, eroded on top.

Ecology. Relatively open sites within forest (montane cloud forests, Podocarpus woods, Pinus plantations) or in the vicinity of the forest, páramo, isolated trees in pastures or orchards; primarily corticolous, occasionally saxicolous.

Distribution. Tropical Andes and Brazil; previously reported from Macaronesia (Clerc 2006) and a southern Atlantic island (Clerc 2011a).

Selected specimens examined. Bolivia: Cochabamba: Cerca de Corani, alrededores de la laguna, $3173 \mathrm{~m}$, 2007, Truong 3878 (G). La Paz: P. N. Cotapata, ruta nueva hasta Coroico, $1 \mathrm{~km}$ despues de Unduavi, 3132 m, 2007, Truong 2984 (G).-Brazil: Minas Gerais: Serra do Caraça, umbebung des Klosters Caraça, 1978, Kalb E Plöbst (private hb.). Parana: Ambrósios (munic. 

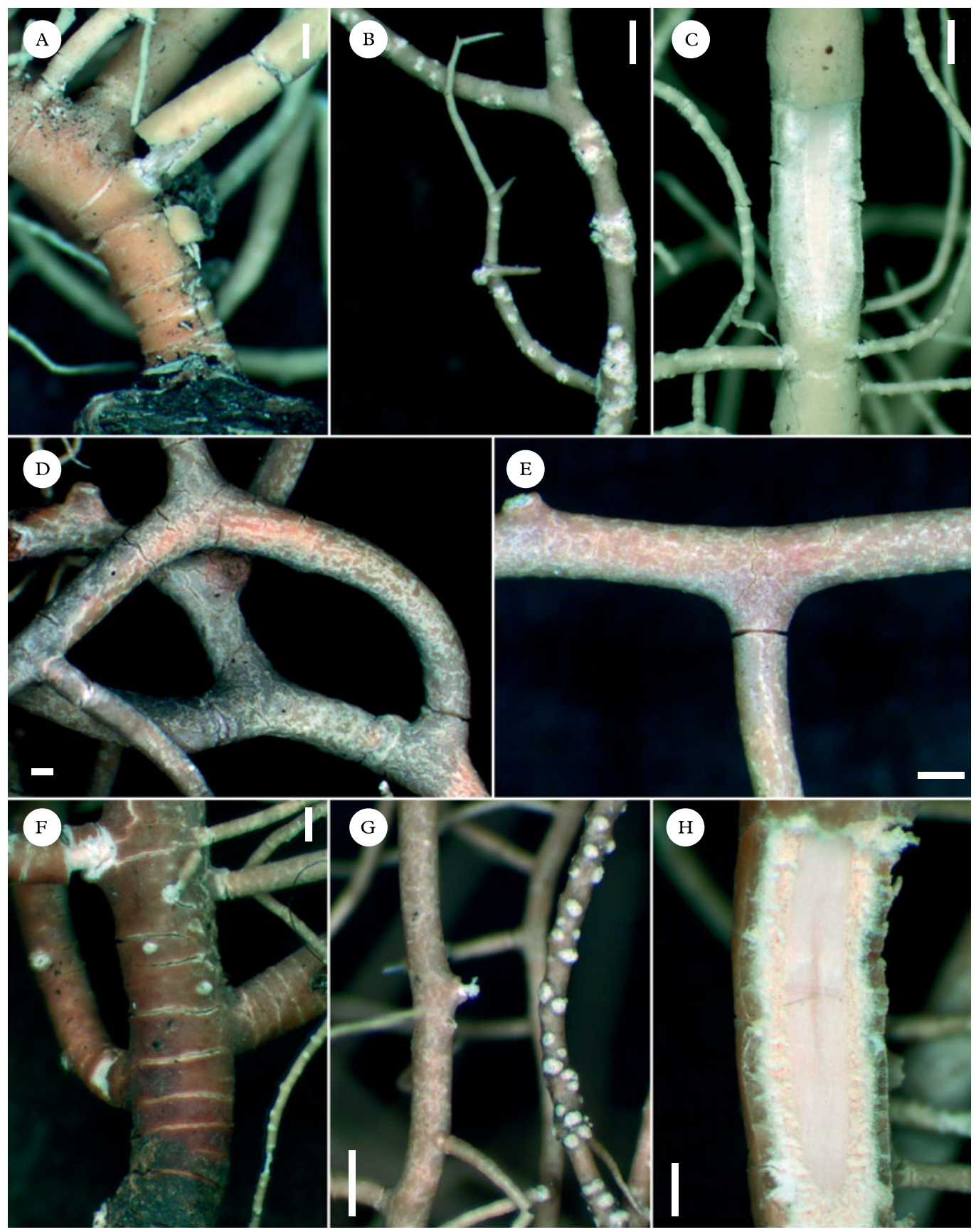

FIG. 8. A-C, Usnea geissleriana; A, trunk concolorous and distinctly annulated (Truong 3386); B, minute soralia aggregating in \pm irregular clusters on lateral/terminal branches (Truong 2984); C, section of branch (Truong 3386). D-H, Usnea regia; D, branches irregular, covered by a network of whitish maculae (Hale 46920); E, cortex surface maculate; lateral branches slightly enlarged at ramification (Mattick 158); F, thin annulations along trunk and basal branches (Kalb \& Plöbst); G, stipitate soralia remaining well-delimited (Kalb $\&$ Plöbst); H, section of branch (Kalb $\mathcal{E}$ Plöbst $)$. Scales $=500 \mu \mathrm{m}$. In colour online. 
Tijucas do Sul), 900 m, 1991, Kummrow \& Cordeiro 3282 (B). Rio de faneiro: P. N. do Itatiáia, $\mathrm{km} \mathrm{11-12} \mathrm{on}$ Planalto road to Agulhas negras, $2400 \mathrm{~m}, 1993$, Marcelli et al. 25175 (H). São Paulo: Serra da Bocaina, 1952, Mattick 16170 (B).-Ecuador: Loja: Ruta nueva hasta Saragura, cerca de Cenen, 2708 m, 2007, Truong 167 (G).-Peru: Cusco: Centro de investigación Wayqecha, trocha Oso, $2742 \mathrm{~m}, 2007$, Truong 2165 (G).-Venezuela: Mérida: Potreros de San Rafael, páramo de Las Colorados, 2950 m, 1975, Hale 44299 (US).

\section{Usnea humboldtii Motyka}

Lich. Gen. Usnea Stud. Monogr. Pars Sys. 2: 608 (1938); type: Venezuela, Silla de Caracas, Humboldt (LBL!lectotype selected here; S! - isolectotype). \% C/M/A: $7 \cdot 5 / 29 \cdot 5 / 26 \cdot 5$. Chemistry: usnic, constictic and diffractaic acids.

Nomenclatural notes. Motyka (1938) indicated that the holotype of $U$. humboldtii was deposited in $\mathrm{B}$, but this specimen appears to be missing. We found one isotype deposited in LBL and designated it as the lectotype. Another isotype deposited in S was considered as isolectotype.

\section{(Fig. 9A-C)}

Thallus pendulous, to more than $20 \mathrm{~cm}$ long; ramifications \pm anisotomic-dichotomous; trunk concolorous with the branches, with distinct annulations; branches cylindrical, tapering only at the apices, distinctly segmented from the base to the apices with large annular cracks, exposing the medulla/axis and sometimes forming bead-like cortical regenerations in between segments (Fig. 9A); branch segments \pm terete and uninflated; lateral branches not constricted at ramification; foveoles and maculae absent; pseudocyphellae absent or scarce on lateral/terminal branches, whitish, minute to thin and elongated (young soralia?); papillae absent; tubercles abundantly covering the main branches (Fig. 9A), large and hemispherical, rarely eroded on top; fibrils slender, scattered to \pm regularly distributed in fishbone pattern; soralia growing from the cortex ad initio on lateral/terminal branches (often bursting at the edges of annular cracks), minute, plane to slightly stipitate, of \pm irregular outline, isolated or aggregating in small packs (Fig. 9B); isidiomorphs few and short; cortex shiny to vitreous in section, thin to moderately thin $(5 \cdot 5-$ $8.5 \%$ ); medulla dense (Fig. 9C), sometimes more compact on basal branches, moderately thick to thick $(24 \cdot 5-31.0 \%)$; axis thin to moderately thin (26.5-35.0\%), with an $\mathrm{A} / \mathrm{M}$ ratio $<1.5$ (Fig. 1).

Apothecia and pycnidia not seen.

Diagnostic notes. Usnea humboldtii is characterized by cylindrical branches segmented by large annular cracks, exposing the medulla/ axis and sometimes forming bead-like cortical regenerations at annulations, and large hemispherical tubercles abundantly covering the main branches. Minute soralia arise from the cortex ad initio on terminal/lateral branches, often bursting at the edges of annular cracks, isolated or aggregating in small packs. The cortex is vitreous and the medulla is dense, reacting $\mathrm{K}+$ yellow turning red (constictic acid, Table 2).

Variation. The abundance of bead-like cortical regenerations, soralia and isidiomorphs may vary among specimens.

Differentiation. Usnea malmei shares the segmented branches, large annular cracks with bead-like cortical regenerations and the vitreous cortex. It differs in the presence of conspicuous elongated pseudocyphellae on the cortex surface, a thicker cortex, thinner and compact medulla and thicker axis, with an $\mathrm{A} / \mathrm{M}$ ratio $>2$ (Fig. 1). Usnea subscabrosa lacks bead-like cortical regenerations at annulations and its CMA values are similar to $U$. malmei, in addition to a $\mathrm{K}$ - medulla (protocetraric acid). Both $U$. malmei and $U$. subscabrosa lack tubercles.

Ecology. Unknown; only historical herbarium specimens were available and their labels didn't contain any information about their ecology.

Distribution. Brazil and Venezuela, rare; also previously reported from Cuba (Motyka 1936).

Selected specimens examined. Brazil: Rio de faneiro: 1867, Glaziou (H).

\section{Usnea malmei Motyka}

Lich. Gen. Usnea Stud. Monogr. Pars Sys. 2: 383 (1938); type: Brazil, Rio Grande Do Sul, 1892, Malme (UPS!holotype; S!-isotype). \% C/M/A: 13.5/13.5/45. Chemistry: usnic, salazinic and norstictic acids, unknown UP1 and UP2 (Herrera-Campos et al. 1998). 

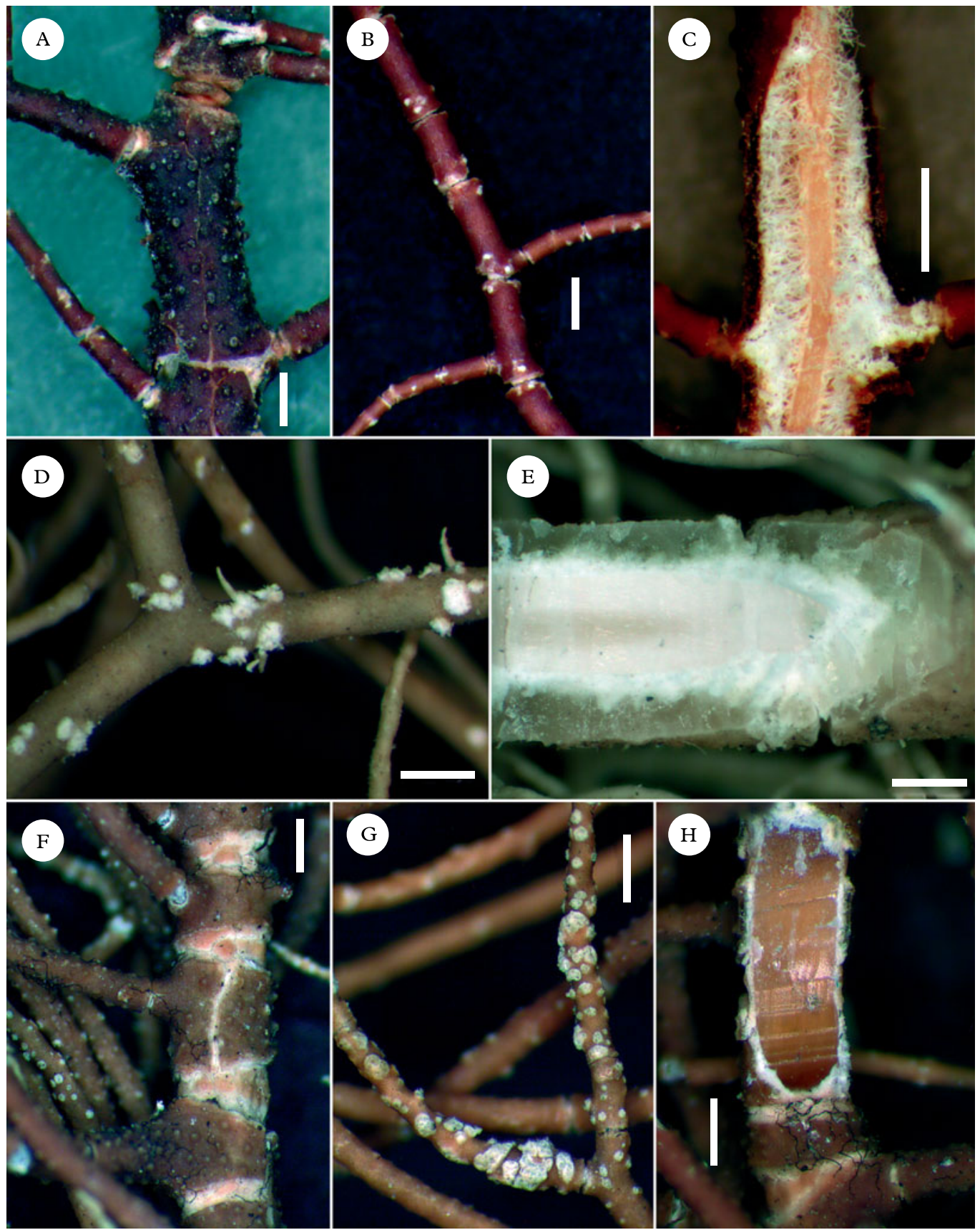

FIG. 9. A-C, Usnea humboldtii (lectotype); A, branches segmented by large annular cracks with bead-like cortical regenerations in between segments; tubercles abundantly covering the branches; $\mathrm{B}$, minute soralia bursting at the edges of annular cracks and aggregating in small packs; C, section of branch. D \& E, Usnea subscabrosa (Sipman E Reyes 34409); D, soralia minute, aggregating in small clusters; E, section of branch. F-H, Usnea transitoria (Denis 1958); F, basal branches with bands of eroded cortex and abundant tubercles; G, soralia aggregating in irregular clusters, without a cortical margin; $\mathrm{H}$, section of branch. Scales $=500 \mu \mathrm{m}$. In colour online. 
Usnea sorediata (Zahlbr.) Motyka, Lich. Gen. Usnea Stud. Monogr. Pars Sys. 2: 382 (1938).-Usnea dasypoga var. plicata f. sorediata Zahlbr., Bull. Herb. Boissier, ser. 2, 18: 467 (1908); type: Brazil, Mono de St. Sebastiano, Damazio (W7446! - holotype). \% C/M/A: 17/7.5/51. Chemistry: usnic, stictic, constictic, menegazziaic, traces of norstictic acids, unknown UP1 and UP2 (HerreraCampos et al. 1998).

Usnea repens Motyka, syn. nov., Lich. Gen. Usnea Stud. Monogr. Pars Sys. 2: 401 (1938); type: Brazil, Minas Geraes, Sao Joao d'el Rey, Malme 315 (S!-holotype; LBL!-isotype). \% C/M/A: $18 \cdot 5 / 5 \cdot 5 / 51 \cdot 5$. Chemistry: usnic and protocetraric acids, unidentified triterpenoids.

(Fig. 6F-H)

Diagnostic notes. A detailed description is available in Herrera-Campos et al. (1998). Usnea malmei is characterized by cylindrical branches segmented by large annular cracks, with eroded edges and bead-like cortical regenerations in between segments (Fig. 6F). Conspicuous elongated pseudocyphellae form white irregular patches on the cortex surface of branches (Fig. 6G). Soralia arise from the cortex ad initio, minute and aggregating when crowded, plane to slightly raised, sometimes convex at maturity, with short isidiomorphs. The cortex is moderately thick to thick, vitreous and hard in section, and the medulla is thin and compact (Fig. $6 \mathrm{H}$ ), with an $\mathrm{A} / \mathrm{M}$ ratio $>2$ (Fig. 1). A pattern of unidentified triterpenoids detected by TLC is characteristic of this species (Fig. 2).

Variation. The abundance of bead-like cortical regenerations at annulations, papillae and soralia may vary among specimens. Six specimens had both soralia and lateral apothecia on the branches. A deeper taxonomic treatment is needed with molecular studies to determine whether U. papillata, the non-sorediate counterpart of U. malmei, belongs to the same species.

Differentiation. See under U. humboldtii. Usnea subscabrosa has a similar thick and vitreous cortex. It differs in the thin annulations, never with bead-like cortical regenerations at annulations, the absence of large pseudocyphellae and a different chemotype without triterpenoids (Table 2). Thin pseudocyphellae may be visible, especially on terminal branches, but they are not as abundant and do not form large patches.
Ecology. Relatively open places within forest (evergreen low montane forests, montane cloud forests) or in the vicinity of the forest, shrubby páramo, montane cerrado, isolated trees in pastures; primarily corticolous, occasionally saxicolous.

Distribution. Tropical Andes and Brazil; previously also reported from Mexico (HerreraCampos et al. 1998).

Selected specimens examined. Brazil: Minas Gerais: Vila Monte Verde, c. $30 \mathrm{~km}$ östlich von Camanducaia, 1978, Kalb \& Plöbst (private hb.). Rio de faneiro: P. N. da Serra dos Orgãos, 1600 m, 1952, Mattick 261 (B). Rio Grande do Sul: Sao Francisco de Paula, Trilha da Estrada do Macaco Branco, 920 m, 2007, Spielmann 5086 (SP). São Paulo: Campos do Jordao, $150 \mathrm{~km}$ nordöstlich von São Paulo, 1700 m, 1978, Kalb \& Plöbst (private hb.)._Colombia: Huila: La Plata, volcan Merenberg, 2600 m, 1984, Aguirre E Sipman 5842 (B).-Peru: Cusco: Santuario histórico de Machu Picchu, ruinas de Intipata, 2728 m, 2007, Truong 687 (G).-Venezuela: Bolivar: Canaima, at Rio Carrao, 650 m, 1990, Sipman 27258 (B). Merida: La Carbonera, sector San Rafael del Macho, 2200 m, 1975, Hale E Lopez-Figueiras 44089 (US). Tachira: El Cobre Chiquito, páramo de Tama, 2700 m, 1975, Hale E Lopez-Figueiras 45548 (US).

\section{Usnea merrillii Motyka}

Lich. Gen. Usnea Stud. Monogr. Pars Sys. 2: 371 (1938); type: USA, Maine, Matinicus Island, 1909, Merrill Lich. Exs. Nr. 64 (W4785!-lectotype). \% C/M/A: 13/16/ 41.5. Chemistry: usnic and salazinic acids (HerreraCampos et al. 1998).

\section{(Fig. 10A \& B)}

Diagnostic notes. Detailed descriptions are available in Herrera-Campos et al. (1998) and Ohmura (2001). Usnea merrillii is characterized by the very flexible and entangled thallus, with several inconspicuous hapters. Branches are thin and cylindrical (terete segments), regularly segmented with bead-like cortical regenerations at annulations (Fig. 10A). Faint to conspicuous whitish maculae are visible on the cortex surface (Fig. 10B), sometimes opening as pseudocyphellae. Soralia remain minute and slightly raised, with short isidiomorphs. The cortex is soft and matt in section, giving a flaccid and soft touch to the thallus. The medulla is thin and compact (Fig. 1), reacting K+ yellow turning red (salazinic \pm galbinic acids, Table 2 ). 

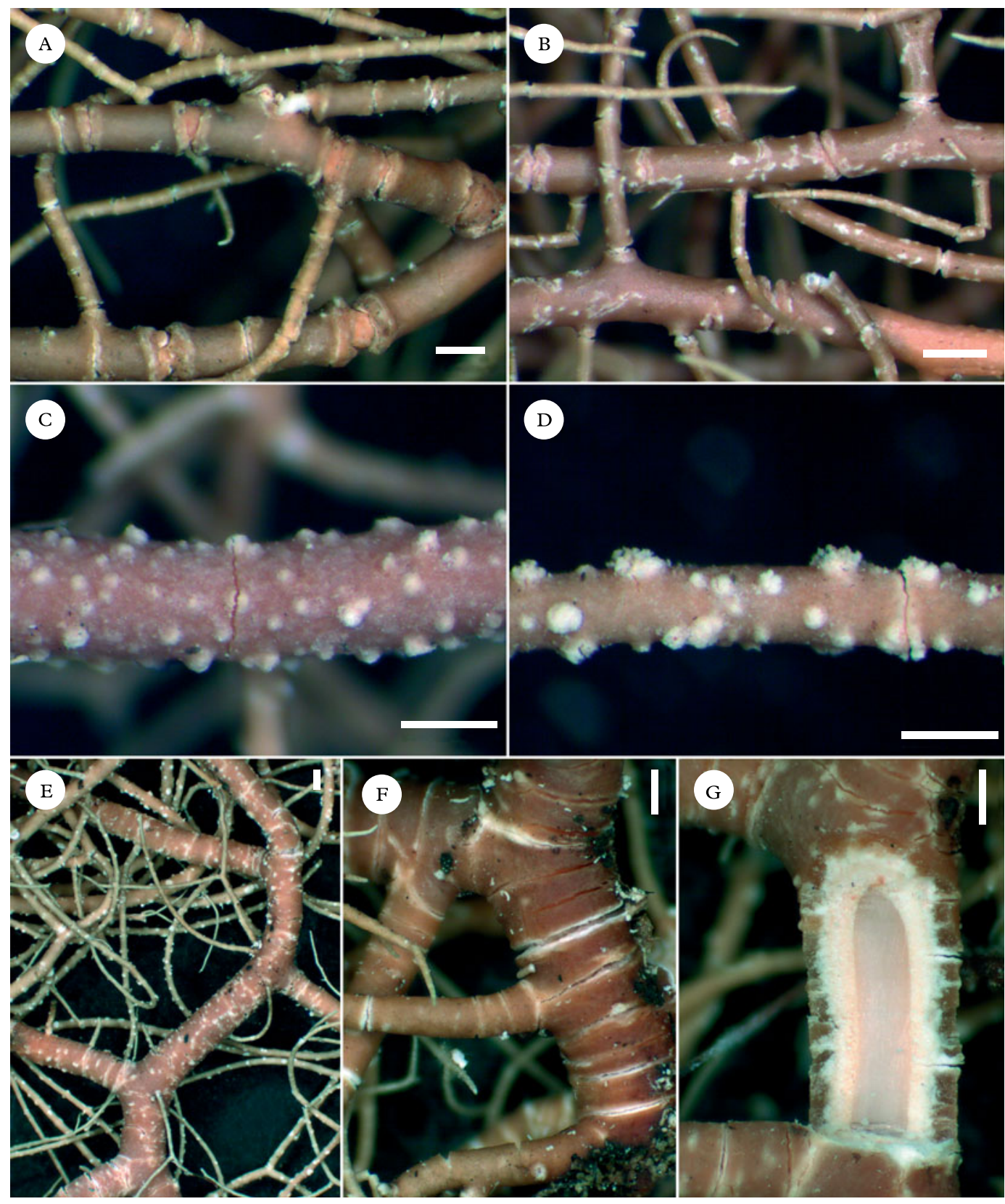

FIG. 10. A \& B, Usnea merrillii (Lopez-Figueiras 17194B); A, branches regularly segmented, with bead-like cortical regenerations in between segments; $\mathrm{B}$, whitish maculae on the cortex surface. $\mathrm{C}-\mathrm{G}$, Usnea subflammea (Hale 45620A); C, eroded tubercles abundantly covering the branches; D, soralia minute and slightly stipitate, remaining well-delimited, with short isidiomorphs; E, cylindrical branches with terete segment; F, thin annulations, most abundant on trunk and basal branches; $\mathrm{G}$, section of branch. Scales $=500 \mu \mathrm{m}$. In colour online. 
Variation. The abundance of bead-like cortical regenerations (rarely almost absent), maculae and soralia may vary among specimens. In addition to salazinic acid, a new chemotype with galbinic acid was detected in South America (Table 2).

Differentiation. Molecular tools are needed to determine if $U$. sancteritae, the fertile counterpart of $U$. merrillii, belongs to a distinct taxon. Usnea subgracilis shares the cylindrical branches with terete segments, and the matt and soft cortex. It differs in the single or few well-visible trunks (thallus not entangled), thin annulations without bead-like cortical regenerations and the $\mathrm{K}$ - reaction of the medulla.

Ecology. Relatively open and humid places within broadleaf or coniferous forests, or in the vicinity of the forest; corticolous.

Distribution. Brazil and Venezuela, rare; previously reported from North America (Motyka 1936; Herrera-Campos et al. 1998) and Japan (Ohmura 2001).

Selected specimens examined. Brazil: Parana: Base do Morro Anhangava, $1000 \mathrm{~m}, 1994$, Poliquesi et al. 167 (B). Rio de faneiro: Serra dos Orgäos, $1950 \mathrm{~m}, 1958$, Schnell 8353 (LBL). São Paulo: Campos do Jordão, 150 km nordöstlich von São Paulo, 1700 m, 1978, Kalb \& Plöbst (private hb.); Campos do Jordão, colonia de Ferias Umuarama, 2006, Gimenes 0152 (SP).-Venezuela: Merida: Estado Lara, un sector del páramo de Los Nepes, 2100-2600 m, 1978, Lopez Figueiras 17194 (US).

\section{Usnea mexicana Vain.}

Dansk Botanisk Arkiv. 4: 3 (1926); type: Mexico, Paso de Doña, 1841, Liebman 7703 (TUR!-lectotype; S!isotype). $\% \mathrm{C} / \mathrm{M} / \mathrm{A}: 5 \cdot 5 / 6 \cdot 5 / 76$. Chemistry: usnic, diffractaic and constictic acids (Herrera-Campos et al. 1998).

Usnea duriuscula Motyka, Lich. Gen. Usnea Stud. Monogr. Pars Sys. 2: 401 (1938); type: Brazil, Serra de Caldas, 1895, Mosén (UPS!- holotpye; S!-isotype). \% C/M/A: $4 \cdot 5 / 11 \cdot 5 / 68$. Chemistry: usnic and protocetraric acids (Herrera-Campos et al. 1998).

(Fig. 11A-E)

Diagnostic notes. A detailed description is available in Herrera-Campos et al. (1998). Usnea mexicana is characterized by the stiff thallus with cylindrical to irregular branches, segmented with \pm thin annulations, eroded at edges (most visible along trunk and basal branches) and often enlarging with extruding medulla and bead-like cortical regenerations in between segments (Fig. 11C). The cortex surface of branches is cracked to areolate (Fig. 11D), sometimes with thin elongated pseudocyphellae. Thick and long fibrils are regularly distributed in a fishbone pattern along the branches. Soralia are minute to slightly enlarging, always slightly stipitate, often crowded on lateral branches (but not fusing), with short isidiomorphs (Fig. 11E). The cortex is matt to \pm shiny in section and the medulla is compact with an $\mathrm{A} / \mathrm{M}$ ratio $>2 \cdot 5$ (Fig. 2). The central axis usually holds a characteristic reddish brown to dark yellow pigmentation (Fig. 11D), visible from the base to the apices (in section).

Variation. This species has a very variable morphology, especially in the shape of branches, \pm cylindrical with terete segments (Fig. 11A) to irregular and often tortuous, with flattened, ridged or even angular segments (Fig. 11B). Cracks (on the cortex surface), pseudocyphellae and bead-like cortical regenerations may vary in abundance. The axis is sometimes fistulose on thick branches. A few specimens lacked the characteristic pigmentation of the central axis, but they otherwise shared the morphology and chemotypes of pigmented specimens, which brought us to the conclusion that this character is variable in this species.

Two chemotypes occur in South America with a strong geographical correlation (Table 2 ): protocetraric acid is the main chemotype in continental South America $(n=13)$, not occurring in the Galapagos, and diffractaic \pm constictic acid is the main chemotype in the Galapagos $(n=10)$, occurring rarely in the continent $(n=2)$.

Differentiation. Due to the wide morphological variation of $U$. mexicana, especially in the shape of branches, specimens with cylindrical branches or lacking axis pigmentation may be difficult to separate from U. subgracilis, both species also sharing one chemotype (protocetraric acid). In U. subgracilis, annulations remain thin, not forming bead-like 

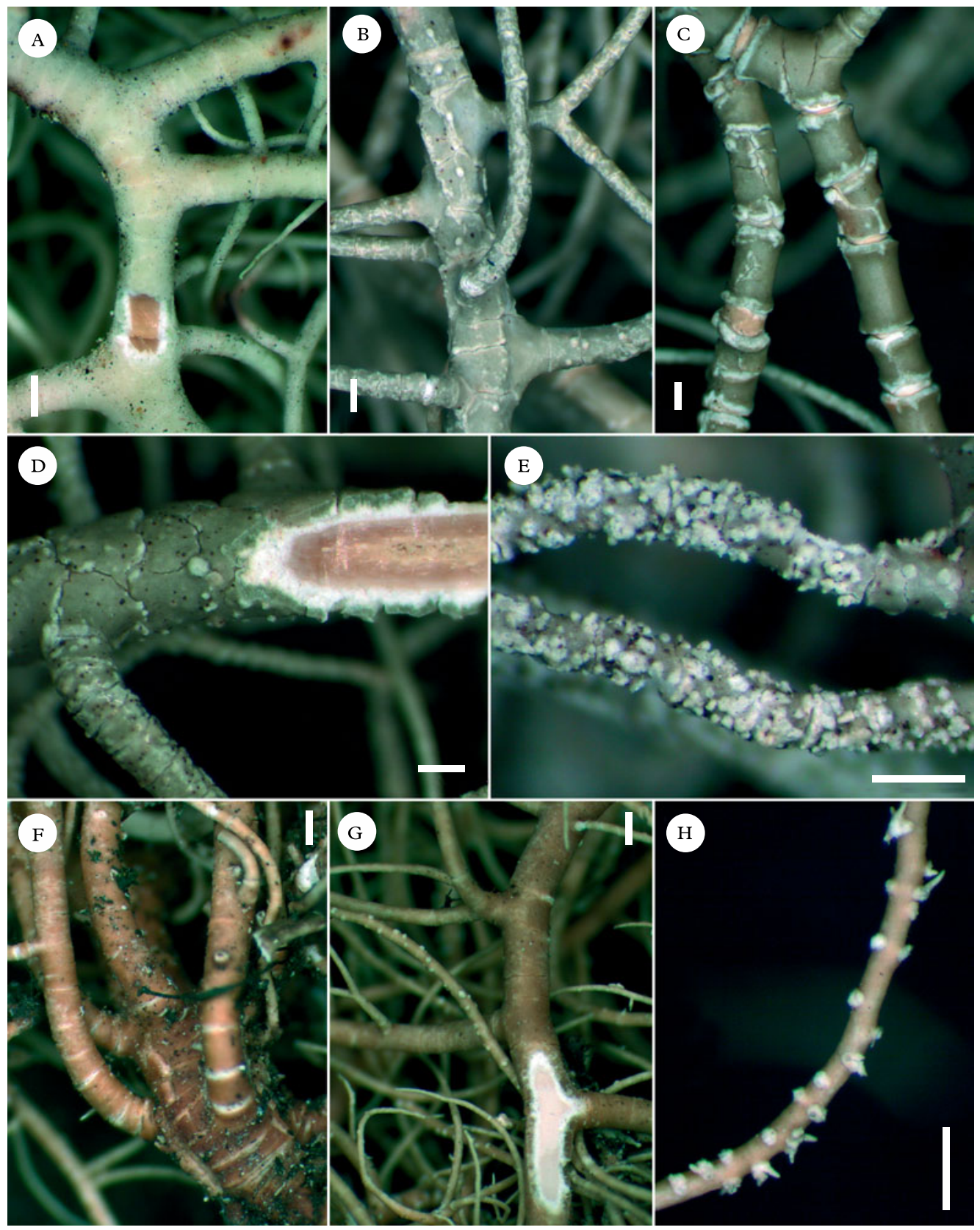

FIG. 11. A-E, Usnea mexicana; A, cylindrical branches with terete segments and thin annulations; axis reddish brown (Clerc 2008-258); B, branches with slightly ridged segments and longitudinal cracks (Bach et al. 634); $\mathrm{C}$, branches with large annulations eroded at edges, with bead-like cortical regenerations in between segments (Bach et al. 634); D, cortex surface cracked; section of branch with axis reddish brown (Bach et al. 634); E, minute soralia crowded on lateral/terminal branches, with short isidiomorphs (Bach et al. 634). F-H, Usnea subgracilis (Kalb \& Plöbst); F, branches segmented with thin annulations, most abundant on trunk and basal branches; G, cortex surface smooth; section of branch; $\mathrm{H}$, minute and slightly raised soralia remaining well-delimited, with short isidiomorphs. Scales $=500 \mu \mathrm{m}$. In colour online. 
cortical regenerations. The cortex surface is smooth, sometimes faintly maculate but never with cracks or pseudocyphellae. The cortex tends to be thicker in section, although values overlap between the two species (Fig. 1). Usnea subgracilis has a flexible thallus with cylindric branches, whereas in $U$. mexicana the thallus is stiffer and branches tend to be more irregular.

A few Andean specimens resemble $U$. mexicana, but with slightly inflated branch segments, a rugose cortex surface without maculae, pseudocyphellae or cracks, minute soralia aggregating and becoming capitate on lateral branches and a thicker cortex $(>10 \%)$, slightly shiny in section. We might be in the presence of a new species and a detailed taxonomic treatment of these taxa over their whole distribution range, including the use of molecular tools, is still required.

Ecology. Relatively open sites within forest (evergreen low montane forests, montane cloud forests, semi-deciduous forests) or in the vicinity of the forest, savannas, isolated trees in pastures; in the Galapagos, from the arid to the humid zone, especially abundant in the transition zone (together with Ramalina usnea). Primarily corticolous, occasionally saxicolous or lignicolous.

Distribution. Tropical Andes, Brazil, and the Galapagos; tropical and subtropical species from the New World (from Mexico in the north to Brazil in the south).

Selected specimens examined. Bolivia: Beni: $20 \mathrm{~km}$ por carretera maderera al SW del km 12 Yucumo - Rurrenabaque, 900 m, 1997, Bach 391 (B). Santa Cruz: Prov. Florida, refugio Los Volcanes, 1000 m, 1997, Bach 634 (B).-Brazil: Matto Grosso: Serra dos Coroados, c. 6 $\mathrm{km}$ südwestlich von Buriti, $600 \mathrm{~m}, 1980$, Kalb (private hb.). Rio de faneiro: P. N. da Serra dos Orgãos, 1600 m, 1952, Mattick 105 (B).-Colombia: Cundinamarca: Cordillera oriental, Gutiérrez a Fosca, 2120 m, 1962, García Barriga 17580 (US). Llanos orientales: Sabanas de Arenisca, 235-700 m, 1959, García Barriga 17106 (US).-Ecuador: Galápagos: Pinzón, from the NEcoast to the highest summit, $300 \mathrm{~m}, 1976$, Sipman 94 (COLO); Pinta, northern slope, $660 \mathrm{~m}, 1970$, Weber 1099 (COLO); Santiago, $4 \mathrm{~km}$ E of the eastern summit, 645 m, 1971, Pike 2770 (COLO); Isabela, Volcán Alcedo, outer E-exposed slope just below the crater rim, 1077 m, 2006, Aptroot 65134 (CDS); Santa Cruz, above Mina Granillo., 597 m, 2008, Truong 1119 (G,
CDS). Imbabura: Reserva ecológica Cotacachi-Cayapas, laguna Piñan, 2786 m, 2007, Truong 778 (G). Loja: P.N. Podocarpus, parte alta desde Los Dos Puentes, alrededores del refugio, 2735 m, 2007, Truong 303 (G). Cusco: Centro de investigación Wayqecha, trocha Wayqecha, 2829 m, 2007, Truong 2186 (G).-Venezuela: Merida: Páramo La Negra between Delgadito and Portachuelo, 2900 m, 1974, Hale 42436 (US). Tachira: slopes of Pico Banberas, páramo de Tama, 2600 m, 1975, Hale E Lopez-Figueiras 45427 (US).

\section{Usnea papillata Motyka}

Lich. Gen. Usnea Stud. Monogr. Pars Sys. 2: 376 (1938); type: Brazil, Minas Geraes, Regnell (UPS L-72218!holotype; S!-isotype). \% C/M/A: 4·5/12 5/66. Chemistry: usnic, stictic, constictic, menegazziaic and norstictic acids, unknown UP1 and UP2 (Herrera-Campos et al. 1998).

Diagnostic notes. A detailed description is available in Herrera-Campos et al. (1998). This is a pendulous, non-sorediate species, usually with lateral apothecia, differing from $U$. malmei only in the absence of soralia. See under U. malmei.

Variation. When apothecia are absent, pycnidia are sometimes visible as globose protuberences on lateral/terminal branches.

Ecology. Semi-deciduous forests, montane cerrado; corticolous, occasionally lignicolous.

Distribution. Bolivia and Brazil, rare; previously reported from Mexico as well (HerreraCampos et al. 1998).

Specimens examined. Bolivia: Cochabamba: $20 \mathrm{~km}$ de Cocapata hacia Cotacajes, 2000 m, 1997, Bach (B).Brazil: Bahia: Chapada Diamantina, zwischen Mundo Novo und Morro do Chapeú, 1000 m, 1980, Kalb (private hb.). Minas Gerais: Parque estatual de Ibitipoca, by administration, $1250 \mathrm{~m}, 1993$, Marcelli et al. $28018(\mathrm{H})$.

\section{Usnea perhispidella J. Steiner}

Sber. Akad. Wiss. Wien, Math.-Natur. Kl. 106: 210 (1897); type: [Kenya], Matchakos, 1896, Liechtenstein E Pospischill (WU!-holotype; W!-isotype). \% C/M/ A: 13/18.5/37. Chemistry: usnic, stictic, constictic, menegazziaic and norstictic acids.

(Fig. 4F-H)

Thallus primarily subpendulous, occasionally erect-shrubby, to c. $20 \mathrm{~cm}$ long; ramifications mostly anisotomic-dichotomous; trunk 
concolorous with the branches; branches slightly to strongly irregular (Fig. $4 \mathrm{~F}$ ), with few, thin and irregularly distributed annulations; branch segments terete to slightly flattened, not inflated; lateral branches not constricted at ramification; foveoles, maculae, pseudocyphellae, papillae and tubercles absent; fibrils \pm slender, rarely spinulous, few (sometimes almost absent) to abundant and irregularly distributed; soralia arising from the cortex ad initio, minute, plane to slightly stipitate, often crowded on the branches from the base to the apices (Fig. 4F), aggregating but without fusing; isidiomorphs usually abundant, growing into isidiofibrils that can completely cover the branches (Fig. 4G); cortex shiny in section, moderately thin to moderately thick $(7-10 \%)$; medulla compact (Fig. $4 \mathrm{H}$ ), thin to moderately thin (13-20\%); axis moderately thick to thick (44.5-56.0\%), with an $\mathrm{A} / \mathrm{M}$ ratio $>2$ (Fig. 1$)$.

Apothecia rare $(n=2)$.

Pycinidia not seen.

Diagnostic notes. Usnea perhispidella is characterized by the erect to subpendulous thallus, with irregular and non-inflated branches, covered by isidiofibrils growing from minute soralia. Fibrils are absent to \pm abundant and irregularly distributed, mostly on basal branches. The cortex is shiny and the medulla is thin and compact $(\mathrm{A} / \mathrm{M}$ ratio $>2)$, reacting $\mathrm{K}+$ yellow (stictic acid, Table 2 ).

Variation. The abundance of fibrils and isidiofibrils tends to vary among specimens, although this species usually has scarce fibrils and abundant isidiofibrils. A few specimens had both apothecia and soralia $(n=3)$.

Differentiation. Thalli of numerous Usnea species infested by parasitic fungi may exhibit branches covered by isidiofibrils, but they are diagnostic in U. perhispidella. Usnea dasaea Stirt. differs in the presence of abundant spinulous fibrils, densely but irregularly distributed, irregular branches \pm constricted at ramification, with slightly to distinctly inflated segments, and soralia aggregating in large irregular clusters on terminal branches. Isidiofibrils are often present, intermixing with fibrils on the branches. This is primarily an erect-shrubby species (included only in the key here), with a thinner cortex (5.5$8.0 \%$ ), a dense and thicker medulla and a thinner axis, with an $\mathrm{A} / \mathrm{M}$ ratio $<1.5$. In South America, both species share one chemotype (stictic acid), otherwise galbinic acid is diagnostic of $U$. dasaea. South American specimens of Usnea dasaea have a very variable morphology, especially in the shape of branch segments and CMA values, and intermediate forms between $U$. dasaea and $U$. perhispidella are common: for example, $U$. perhispidella specimens with the presence of spinulous fibrils or specimens of $U$. dasaea with a thick axis. A deeper taxonomic treatment of these two taxa in their whole distribution range, including the use of molecular tools, is still needed.

Ecology. Relatively open sites within forest (primary and disturbed montane cloud forests, Atlantic forests, relics of Quercus woods) or in the vicinity of the forest, deforested zones of matorral, isolated trees in pastures, in relatively humid places but also in the dry interandean valleys; primarily corticolous, occasionally saxicolous or lignicolous (fenceposts).

Distribution. Tropical Andes and Brazil; previously reported from East Africa (Swinscow \& Krog 1975).

Selected specimens examined. Bolivia: La Paz: Cieneguillas, $1300 \mathrm{~m}$, 1997, Bach 1998 (B).-Brazil: Rio Grande do Sul: Sinimbu, Cava Funda, 500 m, 2004, Spielmann 5701 (SP)._Colombia: Cundinamarca: San Francisco, near Quebrada Cueva Grande, 2500 m, 1986, Sipman 23577 (B). Nariño: Pasto, along main road to Popayan, 2500 m, 1986, Sipman 33646 (B). Santander: Charala, corregimiento Virolín, $1750 \mathrm{~m}$, 1988, Sipman \& Aguirre 27490 (B).-Ecuador: Imbabura: Reserva ecológica Cotacachi-Cayapas, laguna Cuicotcha, 3045 m, 2007, Truong 483 (G).-Peru: Cajamarca: P. N. Cutervo, cerca de San Andres de Cutervo, 2541 m, 2007, Truong 1617 (G). Huanuco: Bosque de Carpish, 2411 m, 2007, Truong 2697 (G).

\section{Usnea regia Motyka}

Lich. Gen. Usnea Stud. Monogr. Pars Sys. 2: 631 (1938); type: Brazil, Minas Geraes, Carassa, Wainio 392 (TUR!-holotype; S!-isotype). \% C/M/A: 9.5/25.5/ 30. Chemistry: usnic, stictic, constictic, menegazziaic, traces of norstictic acids. 
Usnea spinulosa (Müll. Arg.) Motyka, syn. nov., Lich. Gen. Usnea Stud. Monogr. Pars Sys. 2: 408 (1938).Usnea arthroclada var. spinulosa Müll. Arg., Hedwigia $X X X: 225$ (1891); type: Brazil, Supra Joinville in Araucariis, Schenck 4496 (G!-lectotype selected here; G! LBL!-isolectotypes). \% C/M/A: 9/26.5/29. Chemistry: usnic, stictic, constictic, menegazziaic, traces of norstictic acids.

Nomenclatural notes. Müller Argoviensis mentioned two syntypes in his description of $U$. arthroclada var. spinulosa (n. 4496 and n. 4497). Both are hosted in G and correspond to $U$. regia (two specimens within $\mathrm{n}$. 4496 and one within n. 4497). In addition, we found one additional type with n. 4496 in LBL, containing heterogeneous material: one specimen corresponding to $U$. regia and one to U. malmei. Motyka's (1938) description mentions the maculae and the matt cortex of $U$. spinulosa, which matches $U$. regia and not $U$. malmei. We selected one of the specimens on sheet n. 4496 in G as the lectotype.

\section{(Fig. 8D-H)}

Thallus subpendulous to pendulous, to more than $50 \mathrm{~cm}$ long, with a smooth and pruinose cortex surface; ramifications mostly anisotomic-dichotomous; trunk concolorous with the branches or brownish, with thin annulations, rarely a few secondary hapters may be present; branches slightly to strongly irregular (Fig. 8D), regularly segmented with thin annulations along basal branches (Fig. $8 \mathrm{~F})$; branch segments terete to slightly flattened or swollen; lateral branches not to slightly enlarged at ramification (Fig. 8E), sometimes looking like long fibrils (fishbonelike); foveoles absent; maculae very conspicuous on main branches (rarely faint on young thalli), especially towards basal branches, whitish, minute to elongated and drawing a network on the cortex surface of branches (Fig. 8D), opening as elongated pseudocyphellae in mature thalli; papillae and tubercles absent; fibrils absent or scarce and irregularly dispersed on terminal branches (young branches?); soralia arising from the cortex surface ad initio, mainly on lateral/terminal branches (rarely on main branches as well in very developed thalli), slightly to distinctly stipitate, minute to enlarging almost to the branch diameter and becoming slightly capitate at maturity, always remaining well- delimited (Fig. 8G); isidiomorphs few and short; cortex moderately thick to thick $(8 \cdot 5-$ $12.5 \%)$, matt in section; medulla thin to moderately thick (17-24\%), \pm compact (Fig. $8 \mathrm{H}$ ), often with a pink-orange periaxial pigmentation; axis moderately thin to moderately thick (31.5-44.5\%), sometimes pinkish, with an $\mathrm{A} / \mathrm{M}$ ratio $>1.25$ (Fig. 1).

Apothecia and pycinidia not seen.

Diagnostic notes. Usnea regia is characterized by irregular branches segmented by thin annulations along the trunk and basal branches, with a smooth and pruinose cortex surface covered by a network of whitish maculae. Soralia remain slightly stipitate and well-delimited, becoming large and capitate at maturity. The cortex is matt in section and the medulla thin and compact, reacting $\mathrm{K}+$ yellow (stictic acid, Table 2 ).

Variation. Branches have few to numerous ramifications, with lateral branches looking like long fibrils in a fishbone pattern. The abundance of maculae and pruina may vary among individuals, as well as the abundance and size of soralia, in correlation with the development stage of the thallus.

Differentiation. See under U. amabilis and $U$. geissleriana. Usnea subgracilis differs in the cylindrical branches with terete segments, the presence of numerous fibrils and the white medulla reacting $\mathrm{K}-$ (protocetraric acid). The cortex surface is occasionally faintly pruinose or maculate, but never as conspicuously on basal branches.

Ecology. Relatively open sites within forest (mainly in montane cloud forests to the tree limit) or in the vicinity of the forest, shrubby páramo; primarily corticolous, occasionally saxicolous.

\section{Distribution. Tropical Andes and Brazil.}

Selected specimens examined. Bolivia: La Paz: P.N. Cotapata, ruta de la muerte, $2664 \mathrm{~m}, 2007$, Truong 3011 (G).-Brazil: Minas Gerais: Vila Monte Verde, c. $30 \mathrm{~km}$ östlich von Camanducaia, 1978, Kalb E Plöbst (private hb.). São Paulo: Serra do Mar, c. $20 \mathrm{~km}$ östlich 
von Cruzeiro, 1978, Kalb \& Plöbst (private hb.). Rio de faneiro: P. N. da Serra dos Orgãos, campo das Antas near Abrigo 4, 2000 m, 1952, Mattick 166 (B).-Ecuador: Loja: P. N. Podocarpus, lagunas del Compadre, 3000 m, 2007, Truong 256 (G).-Venezuela: Merida: Páramo de Las Coloradas, 2950 m, 1976, Hale 46919 (US).

\section{Usnea sancteritae P. Clerc \& Herrera- Campos}

Bryologist 101: 324 (1998); type: Mexico, Veracruz, Santa Rita, 1992, Herrera-Campos 364 (MEXU!-holotype). \% C/M/A: 8/21/42. Chemistry: usnic and salazinic acids (Herrera-Campos et al. 1998).

Diagnostic notes. A detailed description is available in Herrera-Campos et al. (1998). This is a pendulous, non-sorediate species, differing from $U$. merrillii only in the absence of soralia. It shares with $U$. merrilli the South American chemotype of galbinic acid (Table 2). See under $U$. merrillii.

Variation. The three Brazilian specimens lacked apothecia. In addition, bead-like cortical regenerations were almost absent, but this character seems to be variable in this species (Herrera-Campos et al. 1998). These specimens were recognized by the entangled thallus with several inconspicuous hapters, the thin and cylindrical segmented branches covered by whitish maculae, and the matt and soft cortex.

Ecology. Relatively open and humid places within broadleaf or coniferous forests, or in the vicinity of the forest; corticolous.

Distribution. Brazil, rare; previously reported from Mexico (Herrera-Campos et al. 1998).

Specimens examined. Brazil: Rio de faneiro: P. N. da Serra dos Orgãos, Campo das Antas, 2000 m, 1962, Mattick 166 (B). São Paulo: Itatiaia, Serra da Bocaina, 1962, Mattick 16165 (B).

\section{Usnea subflammea P. Clerc}

Lichenologist 38: 206 (2006); type: Portugal, Azores, Pico [...], $700 \mathrm{~m}, 1993$, Purvis \& Fames 5166 (BM!-holotype; G!-isotype). \% C/M/A: 13.5/13.5/47. Chemistry: usnic, stictic, constictic, menegazziaic and traces of norstictic acids (Clerc 2006).

(Fig. 10C-G)

Diagnostic notes. A detailed description is available in Clerc (2006). Usnea subflammea is characterized by cylindrical branches with terete segments (Fig. 10E), abundantly covered by eroded tubercles (Fig. 10C) and regularly segmented with thin annulations, most abundant along the trunk and basal branches (Fig. 10F). Soralia arise at the top of eroded tubercles, minute and slightly stipitate (Fig. 10D), circular and capitate at maturity, remaining well-delimited (often keeping a cortical margin), with short and often numerous isidiomorphs. The cortex is matt in section, moderately thick to thick (Fig. 1), often with transverse cracks visible in section (Fig. 10G), and the medulla is compact, often with a faint pink-orange periaxial pigmentation, reacting $\mathrm{K}+$ yellow (stictic acid) or $\mathrm{K}+$ yellow turning red (galbinic acid).

Variation. The abundance of papillae, fibrils and fibercles is variable. Tubercles are very conspicuous but their abundance is variable: they are sometimes irregularly distributed or crowded on the branches. Soralia may become plane at maturity, especially on terminal branches, but stipitate soralia are always present. Two chemotypes occur in South America, with stictic acid (as in Macaronesia) or with galbinic acid (Table 2).

Several specimens resembled U. subflammea, but with slightly irregular branches and slightly inflated segments, soralia becoming plane and aggregating in irregular clusters on terminal branches and a denser medulla towards the axis. We might be in the presence of a distinct taxon but we considered these specimens as belonging to U. subflammea s. lat. until more material is available to be studied.

Differentiation. See under U. geissleriana. Both U. columbiana Motyka and U. silesiaca Motyka share with $U$. subflammea the thick and matt cortex and numerous tubercles covering the branches. They differ in the jet black pigmentation of the trunk, extending above the first ramification, and the chemotype of salazinic acid alone. These two species are primarily erect-shrubby (included in the key only) although their thallus size is often large.

Ecology. Primary and disturbed low montane forests and montane cloud forests to 
the upper tree limit, shrubby páramo, isolated trees in pastures; corticolous, occasionally saxicolous.

Distribution. Neotropics (Andes, Brazil, Costa Rica); previously reported from Macaronesia (Clerc 2006).

Selected specimens examined. Bolivia: Cochabamba: Cerca de Corani, alrededores de la laguna, $3173 \mathrm{~m}$, 2007, Truong 581 (G). La Paz: P.N. Cotapata, ruta nueva hasta Coroico, $3132 \mathrm{~m}, 2007$, Truong 2979 (G).-Brazil: Minas Gerais: Umbebung des Klosters Caraça, 1978, Kalb Ë Plöbst (private hb.). Rio de faneiro: P.N. da Serra dos Orgãos, 1600-2000 m, 1952, Mattick $288 b$ (B). São Paulo: Campos do Jordão, $150 \mathrm{~km}$ nordöstlich von São Paulo, 1700 m, 1978, Kalb \& Plöbst (private hb.).-Colombia: Antioquia: Mountain pass $c$. $10 \mathrm{~km}$ NW of Medellín on road to Sta. Fe de Antioquia, 2500 m, 1986, Sipman 33869 (B). Cauca: Silvia, halfway between Piendamo and Silvia, $2300 \mathrm{~m}, 1986$, Sipman 33807 (B). Huila: La Plata, headwaters of Rio La Candelaria, 2300 m, 1984, Aguirre \& Sipman 5810 (B).Costa Rica: San fosé: P.N. Chirripó, Monte sin Fé, 3170 m, 1988, Kappelle 3444 (B).-Ecuador: Loja: P.N. Podocarpus, sendero de las lagunas del Compadre, 3107 m, 2007, Truong 274 (G).-Peru: Cajamarca: P.N. Cutervo, cerca de San Andres de Cutervo, 2714 $\mathrm{m}, 2007$, Truong 1639 (G). Cusco: Centro de investigación Wayqecha, trocha Wayqecha, $2829 \mathrm{~m}, 2007$, Truong 2187 (G)._-Venezuela: Merida: Potreros de San Rafael, páramo de Las Colorados, 2950 m, 1976, Hale 46978 (US). Tachira: base of Cobre Chiquito, páramo de Tama, 2400 m, 1975, Hale \& Lopez-Figueiras 45620 (US).

\section{Usnea subgracilis Vain.}

Ann. Acad. Sci. Fenn. Ser. A 6: 7 (1915); type: Jamaica, 1906, Boergesen (TUR-V513!-lectotype, designated here). \% C/M/A: 12.5/16/43. Chemistry: usnic and protocetraric acids (Clerc 1997).

Usnea hesperina Motyka, Lich. Gen. Usnea Stud. Monogr. Pars Sys. 2: 383 (1938); type: Spain, Tenerife, Las Mercedes, 1924, Czeczott (S!-lectotype, designated here). \% C/M/A: 9·5/24/34. Chemistry: usnic and protocetraric acids.

Usnea elongata Motyka, Lich. Gen. Usnea Stud. Monogr. Pars Sys. 2: 411 (1938); type: Chile, Magualua, Jamuco, 1906, Middleton (S!-holotype). \% C/M/A: 10/16/47. Chemistry: usnic and protocetraric acids (Clerc 1997).

Usnea subplicata (Vain.) Motyka, Lich. Gen. Usnea Stud. Monogr. Pars Sys. 2: 558 (1938)._Usnea gracilis var. subplicata Vain., Ann. Acad. Sci. Fenn. Ser. A 6: 7 (1915); type: Jamaica, 1906, Boergesen (TUR-V527!lectotype, designated here). \% C/M/A: 12.5/16/43. Chemistry: usnic and protocetraric acids (Clerc 1997).

$\neq$ Usnea schadenbergiana Göpp. \& Stein, 60 fahresber. Schles. Ges. Vaterl. Kultur: 229 (1883); type: Philippines, Siriban in Mindanao, Schadenberg (LBL!-holotype; S!-isotype). \% C/M/A: 9/15/52. Chemistry: usnic, stictic, constictic, menegazziaic and norstictic acids (Clerc 1997).

Nomenclatural notes. A careful re-examination of the holotype specimen of $U$. schadenbergiana led us to the conclusion that it doesn't correspond to U. subgracilis/U. hesperina as it had been stated in Clerc (2004): it has more irregular branches, a pigmented axis similar to $U$. mexicana, a blackish base (on the first $\mathrm{mm}$ ) and stictic acid in the medulla. Usnea schadenbergiana is very similar to $U$. mexicana, and several Asiatic specimens identified by Motyka as $U$. schadenbergiana in fact belong to $U$. mexicana. The holotype of $U$. schadenbergiana could represent a juvenile form of $U$. mexicana, but it is necessary to study Asiatic specimens to fully understand the variability of these two taxa. In Asia, Ohmura (2001, 2012) considered $U$. hesperina as a distinct species from $U$. schadenbergiana.

Motyka (1938) indicated that the holotype of $U$. hesperina was deposited in LBL, but this specimen appears to be missing. We found one isotype deposited in S and designated it as the lectotype of $U$. hesperina. Therefore, the neotypes designated by Clerc (1997) or by Lendemer (2006), based on a paratype specimen, are both superfluous.

(Fig. 11F-H)

Diagnostic notes. A detailed description is available in Clerc (1997) and HerreraCampos et al. (1998). Usnea subgracilis is characterized by a soft pendulous thallus, with cylindric branches (terete segments), segmented with thin annulations, most abundant on the trunk and basal branches (Fig. $11 \mathrm{~F})$. Soralia arise from the cortex ad initio, minute and slightly raised, with short isidiomorphs (Fig. $11 \mathrm{H}$ ). They sometimes enlarge on lateral branches, but always remain welldelimited. The cortex surface is matt and relatively smooth (Fig. 11G). The cortex is matt in section (soft to cut), moderately thick to thick, and the medulla is thin and compact, with an $\mathrm{A} / \mathrm{M}$ ratio $>2$ (Fig. 1), reacting $\mathrm{K}-$ (protocetraric acid, Table 2 ).

Variation. Fibrils are few and scattered to abundantly distributed in a fishbone pattern along the branches (Herrera-Campos et al. 
1998). Annulations usually remain thin, sometimes with extruding medulla in between segments, but never forming bead-like cortical regenerations. Faint whitish maculae may be visible on the cortex surface. Segments of branches are sometimes slightly flattened, but in general the branches are cylindrical with terete segments.

Differentiation. See under U. mexicana, $U$. merrillii and $U$. regia.

Ecology. Relatively open sites within primary and secondary forest (evergreen low montane forests, montane cloud forests to the treeline, Quercus woods, Pinus plantations) or in the vicinity of the forest, highlands of páramo and puna, shrubby matorral, isolated trees in pastures; primarily corticolous (including on Quercus, Araucaria and Polylepis), occasionally saxicolous or lignicolous (fencepost).

Distribution. Tropical Andes and Brazil; widely distributed species from temperate and tropical regions (Clerc 1997; HerreraCampos et al. 1998; Ohmura 2001).

Selected specimens examined. Bolivia: Cochabamba: Laguna cerca de Corani, 3173 m, 2007, Truong 583 (G). La Paz: Ruta desde Pelechuco hasta Queara, 3499 m, 2007, Truong 562 (G)._Brazil: Rio de faneiro: Serra da Mantiqueira, zwischen Registro do Picú und Agulhas Negras, 1978, Kalb \& Plöbst (private hb.). São Paulo: Serra da Mantiqueira, Campos do Jordão, $1700 \mathrm{~m}$, 1978, Kalb \& Plöbst (private hb.)._Colombia: Antioquia: Páramo de Frontino al Norte de Urrao, 3500 m, 1985, Churchill 13263 (B). Boyaca: near Arcabuco, 2900 m, 1986, Sipman 34409 (B). Cauca: Popayan, Los Robles, 1750 m, 1986, Sipman 32731 (B). Cundinamarca: Supatá, Alto El Tablazo, 3400 m, 1984, Aguirre E Sipman 5247 (B). Huila: La Plata, volcan Merenberg, 2600 m, 1984, Aguirre \& Sipman 5842 (B). Nariño: along main road to Popayan, $2550 \mathrm{~m}, 1986$, Sipman 33638 (B).-Ecuador: Imbabura: Reserva ecologica Cotacachi-Cayapas, laguna Piñan, $2786 \mathrm{~m}, 2007$, Truong 3249 (G). Loja: Antena militar arriba de San Lucas, 3217 m, 2007, Truong 220 (G). Pichincha: Reserva geobotánica Pululahua, sendero bajando hasta el cráter, 2776 m, 2007, Truong 3341 (G).-Peru: Cajamarca: P. N. Cutervo, cerca de San Andres de Cutervo, 2541 m, 2007, Truong 1611 (G). Cusco: Machu Picchu, ruinas de Intipata, $2728 \mathrm{~m}, 2007$, Truong 691 (G). Huanuco: Bosque de Carpish, $2411 \mathrm{~m}, 2007$, Truong 2696 (G). Pasco: P. N. Yanachaga-Chemillén, trocha hasta la ambra Esperanza, 2554 m, 2007, Truong 2512 (G).Venezuela: Aragua: Cordillera de la Costa, cerca de Tovon, 2200 m, 1979, Vareschi 9785 (H). Merida: beyond cumbres at páramo La Negra, 2800 m, 1974,
Hale 42595 (US). Tachira: base of Cobre Chiquito, valle del páramo de Tama, 2450 m, 1975, Hale \& LopezFigueiras 45663 (US).

\section{Usnea subscabrosa Motyka}

Lich. Gen. Usnea Stud. Monogr. Pars Sys. 2: 313 (1938); type: Portugal, 1877, Newton (H!-holotype). \% C/M/ A: $14 / 13 \cdot 5 / 45$. Chemistry: usnic and protocetraric acids (Clerc 1992).

Usnea santae-annae Motyka, Lich. Gen. Usnea Stud. Monogr. Pars Sys. 2: 315 (1938); type: Brazil, Mato Grosso, Santa Anna da Chapada, 1894, Malme (S!holotype). \% C/M/A: 13/15.5/44. Chemistry: usnic, protocetraric, traces of fumarprotocetraric acids (Clerc 1997).

\section{(Fig. 9D \& E)}

Diagnostic notes. A detailed description is available in Clerc (1992) and Herrera-Campos et al. (1998). Usnea subscabrosa is characterized by a subpendulous to pendulous thallus with tapering branches and terete segments, segmented by thin annulations most abundant along the trunk and basal branches. Soralia arise from the cortex ad initio, usually remaining minute and \pm plane (Fig. 9D), often crowded and aggregating on lateral/ terminal branches, with short isidiomorphs. The thick, hard and vitreous cortex (in section) is very characteristic of this species, together with a thin and compact medulla (Fig. 9E), reacting $\mathrm{K}-$ (protocetraric acid, Table 1).

Variation. This species varies mainly in the abundance of papillae, fibrils, pseudocyphellae, soralia and isidiomorphs. Soralia may slightly enlarge and become capitate at maturity, with a circular to irregular outline, remaining well-delimited or strongly confluent when crowded. Small elongated pseudocyphellae are sometimes visible on thin lateral/ terminal branches.

\section{Differentiation. See under U. malmei.}

Ecology. Primary and disturbed forest (low montane forests, montane cloud forests to the upper treeline, Quercus woods) or in the vicinity of the forest, shrubby páramo, isolated trees in pastures; primarily corticolous, occasionally saxicolous or lignicolous (fence posts). 
Distribution. Tropical Andes and Brazil; previously also reported from North America, south-west Europe and Macaronesia (Halonen et al. 1998; Herrera-Campos et al. 1998; Clerc 2008).

Selected specimens examined. Bolivia: Cochabamba: Comunidad de Saila Pata, 3050 m, 1997, Bach 895 (B).-Brazil: Minas Gerais: vila Monte Verde, c. $30 \mathrm{~km}$ östlich von Camanducaia, 1978, Kalb \& Plöbst (private hb.). Rio de faneiro: Itatiaia, zwischen Registro do Picú und Agulhas Negras, 1978, Kalb \& Plöbst (private hb.). São Paulo: Parque estadual da Serra do Mar, inicio da trilha da Pirapitinga, 915 m, 2007, Spielmann 3339 (SP)._Colombia: Boyaca: near Arcabuco, c. $15 \mathrm{~km}$ on the road towards Tunja, 2900 m, 1986, Sipman $\mathcal{G}$ Reyes 34409 (B). Cauca: Los Robles, campus of Fundacion Universitária, 1750 m, 1986, Sipman 32759 (B). Cundinamarca: San Francisco, vereda Sabaneta, $2500 \mathrm{~m}$, 1986, Sipman 23577 (B). Huila: La Plata, finca Merenberg, 2400 m, 1984, Aguirre E Sipman 5713 (B). Nariño: c. $10 \mathrm{~km} \mathrm{~N}$ of Pasto, along main road to Popayan, 2550 m, 1986, Sipman 33639 (B). Risaralda: Santuario, vereda Las Colonias, $3120 \mathrm{~m}, 1983$, van Reenen E Aguirre 4707 (B). Santander: Charala, corregimiento Virolín, 2000 m, 1988, Sipman E Aguirre 27647 (B).-Ecuador: Loja: Antena militar arriba de San Lucas, 3217 m, 2007, Truong 230 (G).-Peru: Cajamarca: P. N. Cutervo, subiendo al cerro Tarros, $2673 \mathrm{~m}, 2007$, Truong 1727 (G). Cusco: Centro de investigación Wayqecha, trocha Pedriz, $2738 \mathrm{~m}, 2007$, Truong 2241 (G). Huanuco: Bosque de Carpish, $2411 \mathrm{~m}, 2007$, Truong 2708 (G). Pasco: P. N. Yanachaga-Chemillén, trocha hasta la ambra Esperanza, 2482 m, 2007, Truong 2496 (G).-Venezuela: Merida: along road to Portreros de San Rafael, páramo de Las Coloradas, 2400 m, 1976, Hale 46708 (US). Tachira: Base del Cobre Chiquito, páramo de Tama, 2400 m, 1975, Hale E Lopez-Figueiras 45663 (US).

\section{Usnea transitoria Motyka}

Lich. Gen. Usnea Stud. Monogr. Pars Sys. 2: 375 (1938); type: Costa Rica, Santiago de Cartago, potrero above Rio Birris, 1220 m, 1929, Dodge (LBL!-holotype, isotype). \% C/M/A: 5·5/9/71·5. Chemistry: usnic, stictic, constictic, menegazziaic and traces of norstictic acids.

Usnea finkii Zahlbr., syn. nov., Lich. Gen. Usnea Stud. Monogr. Pars Sys. 2: 559 (1938); type: Porto Rico, Aibonito, Fink (W!-holotype; LBL! - isotype). \% C/M/A: 6/10/69. Chemistry: usnic, stictic, constictic, menegazziaic and traces of norstictic acids.

(Fig. 9F-H)

Diagnostic notes. A detailed description is available in Herrera-Campos et al. (1998). Usnea transitoria is characterized by cylindrical branches tapering only close to the apices, with terete to slightly ridged segments and conspicuous bands of eroded cortex with areas of regeneration along main branches (Fig. 9F). Tubercles are large and truncate to conic (Fig. 9F), \pm abundantly but irregularly distributed on main branches. Soralia are plane to slightly stipitate, minute or aggregating in irregular clusters, without a cortical margin (Fig. 9G). The cortex is \pm thin and shiny in section, the medulla is very thin (Fig. 9H) and the axis is one of the largest among the species studied here, with an A/M ratio $>5$ (Fig. 1). As for the type specimens, the chemotype of stictic acid occurs in South America (Table 1).

Variation. The abundance of tubercles and soralia may vary among specimens. A faint pink to brown pigmentation of the axis is sometimes visible.

Differentiation. See under $U$. crenulata. Usnea angulata has squamulose to alate branches and well-delimited soralia with a distinct cortical margin.

Ecology. Montane cloud forests in relatively open sites; corticolous.

Distribution. Venezuela, rare; previously reported from Central America and the West Indies (Motyka 1936; Herrera-Campos et al. 1998).

Selected specimens examined. Venezuela: Distrito Federal: coastal cordillera between Caracas and La Guaira, west of Silla de Caracas, 1600-1800 m, 1941, Santesson 6613 (LBL); cloud forest El Avila, 2000 m, 1958, Denis (LBL).

\section{Uncertain or excluded species}

\section{Usnea regnellii Motyka}

Lich. Gen. Usnea Stud. Monogr. Pars Sys. 2: 374 (1938); type: Brazil, Serra do Itatiaya, 1901, Hemmendorff (S!holotype). \% C/M/A: 7/28/31. Chemistry: usnic, norstictic and connorstictic acids, unidentified triterpenoids.

This is a pendulous, non-sorediate species (with apothecia), with \pm cylindrical branches distinctly segmented by large annulations eroding at edges. The cortex surface is abundantly cracked and the axis is brown-red pigmented. This species most probably belongs to the $U$. firma/himantodes group, which is 
in need of a deeper revision (see under $U$. firma). Non-sorediate species have received very little attention in South America and several taxa are probably yet to be (re-)discovered.

\section{Usnea longissima Motyka}

Lich. Univ.: 626 (1810).
This species has been reported for Colombia (Sipman et al. 2008) and the Galapagos (Weber 1966). It is a Northern Hemisphere species that most probably does not occur in South America. Specimens of $U$. mexicana (in the Galapagos), U. crenulata and several other long pendulous species were commonly misidentified as $U$. longissima.

Key to pendulous Usnea species from tropical South America and the Galapagos

* Primarily erect-shrubby species being occasionally subpendulous (included in the key only)

1 Axis tubular along the whole thallus

eumitrioid species (Truong \& Clerc 2013)

Axis solid, rarely fistulose on the basal branches . . . . . . . . . . . 2

2(1) Cortex red-pigmented, as dots, patches or on a continuous layer . . . . . . . . . $\ldots \ldots \ldots \ldots \ldots \ldots \ldots \ldots$. . . . . . . . . . . . . . . . . . . 2011)

Cortex not red-pigmented . . . . . . . . . . . . . . . . . . . . 3

3(2) Medulla with an orange subcortical pigmentation . . . . . . . . . . . . $\ldots \ldots \ldots \ldots \ldots \ldots \ldots$. . . . . . . subdasaea and allies (Truong et al. 2011)

Medulla not pigmented or pigmentation otherwise $\ldots \ldots \ldots \ldots \ldots$

4(3) Medulla with a pink and/or yellow pigmentation, reacting $\mathrm{C}+$ yellow . . . . . . . . $\ldots \ldots \ldots \ldots$. . . . . . . . ceratina and allies (Truong \& Clerc 2012)

Medulla not pigmented or pigmentation otherwise, not reacting $\mathrm{C}+$ yellow. . . . . 5

5(4) Base with a jet black pigmentation extending above first ramification . . . . . . 6

Base concolorous, brownish or reddish, but not jet black above first ramification . . 7

6(5) Soralia remaining minute with numerous isidiomorphs . . . . . .*U. columbiana

Soralia enlarging to the branch diameter, strongly excavate, without or with few

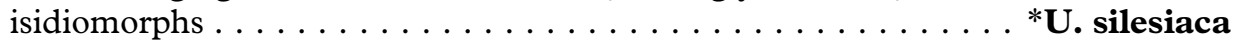

7(5) Soralia absent (punctiform pseudocyphellae may be present); apothecia present or

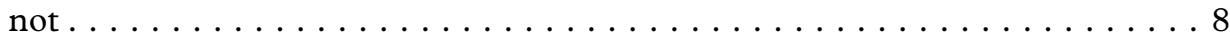

Soralia present . . . . . . . . . . . . . . . . 14

8(7) Thallus very lax due to the extremely thin cortex $(<2.5 \%)$ and $\mathrm{A} / \mathrm{M}$ ratio $(<0 \cdot 25)$; medulla very lax; branches with distinctly swollen segments, constricted at ramification (fusiform); punctiform pseudocyphellae sparsely present on the branches; apothecia often absent . . . . . . . . . . . . . . . U. articulata

Thallus not so lax; cortex, $\mathrm{A} / \mathrm{M}$ ratio and medulla otherwise; branches not distinctly fusiform; pseudocyphellae and apothecia present or not . . . . . . . . . 9

9(8) Branch segments distinctly alate, squamulose or strongly ridged . . . . . . U. alata Branch segments terete, flattened and/or inflated, not alate, squamulose or ridged . . 10

10(9) Cortex vitreous and hard in section; large elongated pseudocyphellae abundantly covering the branches. . . . . . . . . . . . . . . . . papillata

Cortex matt to shiny, not vitreous; pseudocyphellae absent or if present remaining

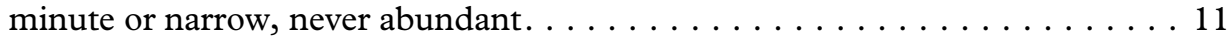


11(10) Medulla reacting K-, PD+ orange (protocetaric acid) . . . . . . . . U. firma Medulla reacting $\mathrm{K}+$ yellow, orange, $r e d, \mathrm{PD}+$ or $-\ldots \ldots \ldots 12$

12(11) Branches cylindrical with terete segments; fibrils present and usually numerous; cortex surface not pruinose . . . . . . . . . . . . . sancteritae

Basal branches irregular, with \pm flattened or swollen segments; fibrils absent or very scattered (for example at the apices of branches); cortex surface slightly to strongly pruinose .......................... 13

13(12) Thallus entangled, with several inconspicuous hapters; maculae absent or faint on the cortex surface, with instead minute pseudocyphellae on main branches; often both soralia and apothecia absent; constictic without stictic acid; Andes

U. amabilis

Thallus (sub)pendulous or entangled; maculae conspicuously spotting the cortex surface or aggregating in irregular clusters; apothecia usually present; constictic with stictic acids; Brazil . . . . . . . . . . . . . . . . U. arthroclada

14(7) Branch segments distinctly alate, with large trapezoid segments at ramification . . .

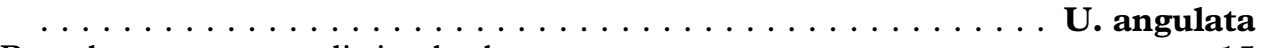

Branch segments not distinctly alate. . . . . . . . . . . . 15

15(14) Cortex eroding in large and well-delimited bands (with areas of regeneration) along basal branches; large hemispherical tubercles abundantly but irregularly distributed on main branches; medulla $\mathrm{K}+$ yellow (stictic acid) . . . . . . . . U. transitoria

Large bands of eroded cortex absent; tubercles present or not; medulla K+ or K- . 16

16(15) Branch segments distinctly ridged to squamulose; cortex surface eroding and/or desquamating along ridges. . . . . . . . . . . . . . 17

Branch segments terete, flattened or deformed (at the most slightly ridged), not distinctly ridged or squamulose; cortex surface smooth or cracked, not eroding/ desquamating or only at the edges of annulations . . . . . . . . . 18

17(16) Branch segments strongly ridged; cortex eroding along ridges and transverse fissures, not to slightly desquamating; soralia minute, crowded and aggregating on lateral/ terminal branches, without a cortical margin; medulla $\mathrm{K}-$ (triterpenoids) . . . . . .

$\ldots \ldots \ldots \ldots \ldots \ldots \ldots \ldots \ldots$. crenulata

Branch segments squamulose; cortex strongly desquamating on the whole surface of branch; soralia minute to circular, well-delimited even when crowded with a distinct cortical margin; medulla $\mathrm{K}+$ or $\mathrm{K}-$ (norstictic and/or triterpenoids) . . . .

$\ldots \ldots \ldots \ldots \ldots \ldots \ldots \ldots \ldots \ldots$. angulata $\mathrm{\ldots} . \ldots \ldots$ lat.

18(16) Axis pigmented in ochraceous brown to dark yellow . . . . . . . U. mexicana Axis not pigmented or pigmentation faint pink to orange . . . . . . . . . . 19

19(18) Cortex surface cracked to areolate; branches segmented with annular cracks eroding at the edges and often forming bead-like cortical regenerations; thick and long fibrils distributed in fishbone pattern; medulla compact with an $\mathrm{A} / \mathrm{M}$ ratio $>2.5 \ldots$ $\ldots \ldots \ldots \ldots \ldots \ldots \ldots \ldots \ldots$. . . . . . . . . . . . . . . . . . . . . . .

Cortex surface smooth, possibly with maculae or pseudocyphellae but not cracked or

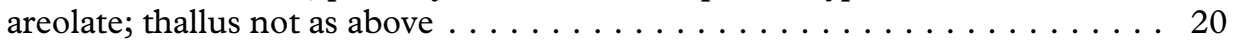

20(19) Cortex matt in section; cortex surface pruinose or not . . . . . . . . . . 21

Cortex shiny to vitreous in section; cortex surface not pruinose. . . . . . . . 26

21(20) Branches abundantly covered by large tubercles, eroded on top . . U. Uubflammea Tubercles absent or scarce on branches . . . . . . . . . . . . 22

22(21) Basal branches cylindrical with terete segments . . . . . . . . . . . . 23 Basal branches irregular, with terete, flattened or swollen segments. . . . . . . . 24 
23(22) Thallus entangled with several inconspicuous hapters; branches very thin and segmented with bead-like cortical regenerations in between segments; medulla $\mathrm{K}+$ ............................. U. merrillii

Thallus pendulous with a single or few well-visible trunks; branches segmented with thin annulations, sometimes eroded at edges with extruding medulla, but without bead-like cortical regenerations; medulla $\mathrm{K}-\ldots \ldots \ldots$. . . U. subgracilis

24(22) Thallus entangled with several inconspicuous hapters, not annulated; soralia often scarce, minute and plane, not enlarging or coalescing; constictic without stictic acid ......................... . amabilis

Thallus pendulous with a single or few well-visible trunks, distinctly annulated; soralia usually abundant, plane to distinctly stipitate, enlarging or coalescing in large clusters; constictic with stictic acid. . . . . . . . . . . . . . 25

25(24) Maculae very conspicuous, drawing a network on the cortex surface of main branches; soralia distinctly stipitate, remaining well-delimited; medulla compact and $\mathrm{A} / \mathrm{M}$ ratio usually $>1.25 \ldots \ldots \ldots \ldots \ldots \ldots$ U. regia

Maculae absent or faintly spotting the cortex surface; soralia plane to slightly stipitate, coalescing in irregular clusters; medulla dense and $\mathrm{A} / \mathrm{M}$ ratio $<1.5$

U. geissleriana

26(20) Branches covered by numerous isidiofibrils (growing from minute soralia) and/or spinulous fibrils, densely but irregularly distributed on the branches . . . . . . 27

Isidiofibrils and/or spinulous fibrils absent or not very abundant . . . . . . . 28

27(26) Medulla thin and compact, with $\mathrm{A} / \mathrm{M}$ ratio $>2$; branches not inflated nor constricted at ramification; soralia remaining minute, crowded on the branches from the base to the apices; isidofibrils usually abundant (may have fallen off on older thalli), often completely covering the branches; fibrils absent to abundantly but irregularly distributed, usually not spinulous . . . . . . . . . U. perhispidella

Medulla thick and dense, with $\mathrm{A} / \mathrm{M}$ ratio $<1.5$; branches slightly to distinctly inflated and constricted at ramification; soralia aggregating in irregular clusters on terminal branches; isidiofibrils absent to abundant, intermixed with fibrils; fibrils spinulous, densely but irregularly covering the branches . . . . . . . . . . .

*U. dasaea s. lat. (see under U. perhispidella)

28(26) Branch segments terete and not inflated; branches not constricted at ramification 29

Branch segments flattened, deformed and/or inflated; branches constricted or not at

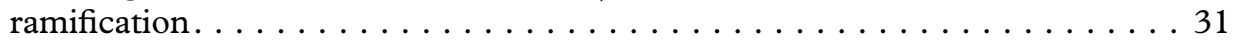

29(28) Cortex $<8.5 \%$ and medulla dense, with an $\mathrm{A} / \mathrm{M}$ ratio $<1.5$; large hemispherical tubercles (rarely eroded on top) abundantly covering the branches . $\ldots \ldots \ldots \ldots \ldots \ldots \ldots \ldots \ldots \ldots$. . . . . . . . . . . . . . . . . . . . . . .

Cortex $>8.5 \%$ and medulla compact, with an $\mathrm{A} / \mathrm{M}$ ratio $>2$; tubercles if present,

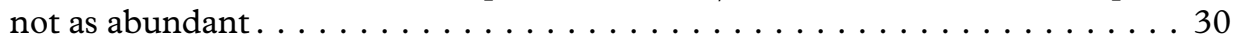

30(29) Conspicuous large pseudocyphellae covering the branches; branches segmented with large annular cracks, exposing the medulla/axis and often forming bead-like cortical regenerations in between segments; medulla $\mathrm{K}+$ or $\mathrm{K}-$ (triterpenoids) $\ldots \ldots \ldots \ldots \ldots \ldots \ldots \ldots \ldots \ldots$. . . . . . . . . . . . . . . . . . . . . . .

Pseudocyphellae absent or thin and restricted to lateral/terminal branches; branches segmented with thin annulations, not forming bead-like cortical regenerations; medulla $\mathrm{K}-$ (protocetraric acid) . . . . . . . . . . . U. subscabrosa 
31(28) Thallus very fragile due to the extremely thin cortex $(<4.5 \%)$ and an $\mathrm{A} / \mathrm{M}$ ratio $<0.5$; branches strongly deformed with inflated segments; foveoles very

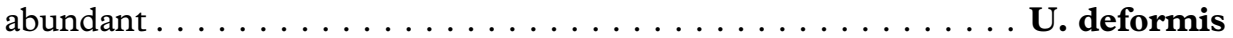

Thallus not very fragile, with a thicker cortex $(>4.5 \%)$ and an $\mathrm{A} / \mathrm{M}$ ratio $>0.5$; branches deformed or not; foveoles present or not . . . . . . . . . . 32

32(31) Soralia becoming plane and fusing to cover the apices of branches; cortex $>7 \%$; tubercles usually abundant; triterpenoids . . . . . . . . . . . U. dodgei

Soralia aggregating in irregular clusters but not fusing to cover the apices of branches; cortex $<7 \%$; tubercles absent or scarce; triterpenoids absent . . . . . . . 33

33(32) Thallus subpendulous to pendulous; branches irregular, with deformed and sometimes \pm inflated segments, not to slightly constricted at ramification; soralia distinctly capitate at maturity . . . . . . . . . . . . . . U. dimorpha

Thallus erect-shrubby to subpendulous; branches tapering with terete and distinctly inflated segments, distinctly constricted at ramification; soralia plane to slightly

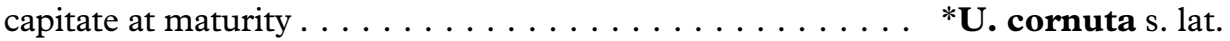

Fieldwork was supported by the Conservatoire et Jardin Botaniques de la Ville de Genève, a grant "Augustin Lombard" from the Société de Physique et d'Histoire Naturelle de Genève and a grant from the Amazon Conservation Association. Fieldwork was realized with the collaboration of the herbaria CDS, LPB, QCNE, USM and the Wayqecha Biological Station (Peru). F. Bungartz (CDS), M. Herrera-Campos (MEXU), C. Aldana Munguia, A. Cuba Villena, M. F. Collaguazo, Y. Manami, A. Ramirez-Ordaya, P. Rodriguez, L. Salcedo Valdez and A. $\mathrm{X}$. Shuguli participated in the field trips. The Ministries of Environment of Bolivia, Peru, Ecuador and the Galapagos provided collection permits. The staff in national parks kindly supported our investigation by providing guides and/or lodging. A. Tehler and W. Mulenko gave us a warm welcome during our visits to $S$ and LBL, and curators of the cited herbaria kindly sent specimens on loan. F. Visentin helped with TLC analysis and M. Price corrected the English.

\section{REFERENCES}

Aptroot, A. \& Bungartz, F. (2007) The lichen genus Ramalina on the Galapagos. Lichenologist 39: 519542.

Arvidsson, L. (1991) Lichenological studies in Ecuador. In Tropical Lichens: Their Systematics, Conservation, and Ecology, Vol. 43 (D. J. Galloway, ed.): 123134. Oxford: Clarendon Press.

Awasthi, G. (1986) Lichen genus Usnea in India. Fournal of the Hattori Botanical Laboratory 61: 333-421.

Clerc, P. (1987a) On the morphology of soralia in the genus Usnea. Bibliotheca Lichenologica 25: 99-102.

Clerc, P. (1987b) Systematics of the Usnea fragilescens aggregate and its distribution in Scandinavia. Nordic Fournal of Botany 7: 479-495.

Clerc, P. (1992) Some new or interesting species of the genus Usnea (lichenised Ascomycetes) in the British Isles. Candollea 47: 513-526.
Clerc, P. (1997) Notes on the genus Usnea Dill. ex Adanson. Lichenologist 29: 209-215.

Clerc, P. (1998) Species concepts in the genus Usnea (lichenized Ascomycetes). Lichenologist 30: 321-340.

Clerc, P. (2004) Notes on the genus Usnea Adanson. II. Bibliotheca Lichenologica 88: 79-90.

Clerc, P. (2006) Synopsis of Usnea (lichenized Ascomycetes) from the Azores with additional information on the species in Macaronesia. Lichenologist 38: 191-212.

Clerc, P. (2008) Usnea. In Lichen Flora of the Greater Sonoran Desert Region, Vol. 3 (T. H. Nash III, C. Gries \& F. Bungartz, eds.): 302-335. Tempe, Arizona: Lichens Unlimited, Arizona State University.

Clerc, P. (2011a) Notes on the genus Usnea Adans. (lichenized Ascomycota). III. Bibliotheca Lichenologica 106: 41-51.

Clerc, P. (2011b) Usnea. In Nordic Lichen Flora Vol. 4 (A. Thell \& R. Moberg, eds): 107-127. Uddevalla: Nordic Lichen Society.

Clerc, P. \& Herrera-Campos, M. A. (1997) Saxicolous species of Usnea subgenus Usnea (lichenized Ascomycetes) in North America. Bryologist 100: 281301.

Culberson, C. F. \& Ammann, K. (1979) Standardmethode zur Dünnschichtchromatographie von Flechtensubstanzen. Herzogia 5: 1-24.

Culberson, C. F. \& Johnson, A. (1982) Substitution of methyl tert.-butyl ether for diethyl ether in the standardized thin-layer chromatographic method for lichen products. Fournal of Chromatography 238: 483-487.

Halonen, P., Clerc, P., Goward, T., Brodo, I. M. \& Wulff, K. (1998) Synopsis of the genus Usnea (lichenized Ascomycetes) in British Columbia, Canada. Bryologist 101: 36-60.

Halonen, P., Myllys, L., Ahti, T. \& Petrova, O. V. (1999) The lichen genus Usnea in East Fennoscandia. III. The shrubby species. Annales Botanici Fennici 36: 235-256. 
Herrera-Campos, M. A., Clerc, P. \& Nash III, T. H. (1998) Pendulous species of Usnea from the temperate forests in Mexico. Bryologist 101: 303-329.

Herrera-Campos, M. A., Nash III, T. H. \& Garcia, A. Z. (2001) Preliminary study of the Usnea fragilescens aggregate in Mexico. Bryologist 104: 235-259.

Lendemer, J. C. (2006) Nomenclature and typification in the genus Usnea (lichenized Ascomycetes) - V. Usnea hesperina Motyka. Proceedings of the Academy of Natural Sciences of Philadelphia 155: 25-27.

Lendemer, J. C. \& Tavares, I. I. (2003) Nomenclature and typification in the genus Usnea (lichenized Ascomycetes)-II. Usnea fallax and Usnea paradoxa. Proceedings of the Academy of Natural Sciences of Philadelphia 153: 181-185.

Lendemer, J. C. \& Tavares, I. I. (2004) Nomenclature and typification in the genus Usnea (lichenized Ascomycetes)-III. Usnea alata and Usnea sulcata. Sida [Dallas] 21: 643-650.

Lumbsch, H. T. \& Wirtz, N. (2011) Phylogenetic relationships of the neuropogonoid core group in the genus Usnea (Ascomycota: Parmeliaceae). Lichenologist 43: 553-559.

Moore, B. J. (1968) The macrolichen flora of Florida. Bryologist 71: 161-266.

Motyka, J. (1936) Lichenum Generis Usnea Studium Monographicum. Pars Systematica (Vol. 1). Leopoldi: privately printed.

Motyka, J. (1938) Lichenum Generis Usnea Studium Monographicum. Pars Systematica (Vol. 2). Leopoldi: privately printed.

Ohmura, Y. (2001) Taxonomic study of the genus Usnea (lichenized Ascomycetes) in Japan and Taiwan. Fournal of the Hattori Botanical Laboratory 90: 1-96.

Ohmura, Y. (2012) A synopsis of the lichen genus Usnea (Parmeliaceae, Ascomycota) in Taiwan. Memoirs of the National Museum of Nature and Science, Tokyo 48: $91-137$.

Ohmura, Y., Lin, C. K. \& Wang, P. H. (2010) Three sorediate species of the genus Usnea (Parmeliaceae, Ascomycota) new to Taiwan. Memoirs of the $\mathrm{Na}$ tional Museum of Nature and Science, Tokyo 46: 6976.

Poelt, J. (1970) Das Konzept der Artenpaare bei den Flechten. Deutsche Botanische Gesellschaft, neue Folge 4: 187-198.

Rodriguez, J. M., Estrabou, C., Truong, C. \& Clerc, P. (2011) The saxicolous species of the genus Usnea subgenus Usnea (Parmeliaceae) in Argentina and Uruguay. Bryologist 114: 504-525.

Seymour, F. A., Crittenden, P. D., Wirtz, N., Øvstedal, D. O., Dyer, P. S. \& Lumbsch, H. T. (2007) Phylogenetic and morphological analysis of Antarctic lichen-forming Usnea species in the group Neuropogon. Antarctic Science 19: 71-82.

Sipman, H. J. M. (1995) Preliminary review of the lichen biodiversity of the Columbian montane forests. In Biodiversity and Conservation of Neotropical Montane
Forests (S. P. Churchill, H. Balsley, E. Forero \& J. L. Luteyn, eds): 313-320. New York: New York Botanical Garden.

Sipman, H. J. M. (1999) Lichens. In Páramos: a Checklist of Plant Diversity, Geographical Distribution, and Botanical Literature (J. L. Luteyn, ed.): 41-53. New York: New York Botanical Garden.

Sipman, H. J. M., Hekking, W. \& Aguirre Ceballos, J. (2008) Checklist of Lichenized and Lichenicolous Fungi from Colombia (Biblioteca José Jerónimo Triana Vol. 20). Bogotá: Instituto de Ciencias Naturales, Facultad de Ciencias, Universidad Nacional de Colombia.

Stevens, G. N. (1999) A revison of the lichen family Usneaceae in Australia. Bibliotheca Lichenologica 72: 1128.

Stevens, G. N. (2004) Usneaceae. In Flora of Australia Vol. 56A, Lichens 4 (P. M. McCarthy \& K. Mallett, eds): 78-98 \& 107-115. Melbourne: ABRS/CSIRO.

Swinscow, T. D. V. \& Krog, H. (1975) The Usnea undulata aggregate in East Africa. Lichenologist 7: 121138.

Swinscow, T. D. V. \& Krog, H. (1976) The Usnea articulata aggregate in East Africa. Norwegian fournal of Botany 23: 261-268.

Swinscow, T. D. V. \& Krog, H. (1978) Pendulous species of Usnea in East Africa. Norwegian Fournal of Botany 25: 221-241.

Swinscow, T. D. V. \& Krog, H. (1979) The fruticose species of Usnea subgenus Usnea in East Africa. Lichenologist 11: 207-252.

Truong, C. \& Clerc, P. (2012) The lichen genus Usnea (Parmeliaceae) in tropical South America: species with a pigmented medulla, reacting $\mathrm{C}+$ yellow. $\mathrm{Li}$ chenologist 44: 1-13.

Truong, C. \& Clerc, P. (2013) Eumitrioid Usnea species (Parmeliaceae, lichenized Ascomycota) in tropical South America and the Galapagos. Lichenologist 45: 383-395.

Truong, C., Bungartz, F. \& Clerc, P. (2011) The lichen genus Usnea (Parmeliaceae) in the tropical Andes and the Galapagos: species with a red-orange cortical or subcortical pigmentation. Bryologist 114: 477503.

Walker, F. J. (1985) The lichen genus Usnea subgenus Neuropogon. Bulletin of the British Museum (Natural History), Botany 13: 1-130.

Weber, W. A. (1966) Lichenology and bryology in the Galápagos Islands, with checklists of the lichens and bryophytes thus far reported. In The Galápagos. Proceedings of the Symposium of the Galápagos International Scientific Project (R. I. Bowman, ed.): 197200. Berkeley: University of California Press.

Wirtz, N., Printzen, C. \& Lumbsch, H. T. (2008) The delimitation of Antarctic and bipolar species of neuropogonoid Usnea (Ascomycota, Lecanorales): a cohesion approach of species recognition for the Usnea perpusilla complex. Mycological Research 112: 472-484. 